Int. J. Dev. Biol. 53: 1-17 (2009)

doi: $10.1387 / \mathrm{ijdb} .082573 \mathrm{gt}$

\title{
Neural stem cells at the crossroads: MMPs may tell the way
}

\author{
GAETANA A. TONTI ${ }^{1}$, FERDINANDO MANNELLO ${ }^{*}, 1$, EMANUELE CACCI ${ }^{2}$, and STEFANO BIAGIONI ${ }^{2}$ \\ ${ }^{1}$ Department of Biomolecular Sciences, Section of Clinical Biochemistry, Faculty of Sciences and Technologies, University "Carlo Bo", \\ Urbino and 2Department of Cell and Developmental Biology, "La Sapienza" University, Rome, Italy
}

\begin{abstract}
Matrix metalloproteinases (MMP) constitute a family of more than 25 enzymes which process a large number of pericellular substrates. Even though initially reported to have an ability to degrade almost all of the extracellular components, MMP are now known to play roles which are not limited to the breakdown of extracellular barriers. In fact, MMPs regulate many biological processes, being involved not only in physiological events, but also in pathological processes. Strikingly, MMPs have been found to be involved in the physiology of the Central Nervous System (CNS), taking part and playing important roles in several processes such as repair and ontogeny, as well as in pathological conditions of the CNS. Initially considered to be a "static" structure, lacking regenerative capability, the CNS has been considered for a long time to be a system without renewal capabilities. Recently, the discovery of constant neural replacement has changed our way of considering the adult brain, and the finding of the existence of neural stem cells has opened the way to exciting and fascinating perspectives of the CNS. So, could MMPs, originally found during metamorphosis in tadpoles, and now amazingly identified in the CNS, have something to do in neuronal function? In this review we take into consideration the possible roles of two metalloproteinases, MMP-2 and MMP-9, also called gelatinases, in controlling several aspects of CNS organization, including the modulation of neural stem cell properties and the differentiation of their progeny, both under normal and pathophysiological conditions.
\end{abstract}

KEY WORDS: Central Nervous System, matrix metalloproteinase, differentiation, development

\section{Introduction}

What the famous aphorism "Panta rei"says, indicating that reality is not something static and immutable, but is in a state of constant transformation, turned out to be true even for the Central Nervous System (CNS), which has long been considered as a static structure, and regarded as an inhibitory microenvironment for neuronal regeneration. In fact, for a long time neurogenesis was thought not to take place in the adult CNS, while gliogenesis might have occurred only under certain particular circumstances. However, reports show that the adult CNS represents an environment where neurogenesis does occur, involving processes such as proliferation, fate determination, migration and integration of neuronal progenitors into the complex neuronal network (Gage, 2000), with the involvement of extracellular proteinases crucial for CNS pathophysiology (Yong et al., 2001). In different areas of the adult brain there is a continuous production of neurons which goes on through- out life time as a normal feature of the adult CNS, integrating the already existent neuronal circuitry (Lledo et al., 2006). In order to allow such modifications in the microenvironment and to permit the flexible behaviour of neural precursors, many physiological modifications need to take place, regulating the fascinating plasticity of the adult CNS. In fact, for the correct evolution of any biological system, and even more for such a complex and intricate system as the CNS, continuous and finely regulated interactions between each cell and the surrounding environment are necessary and fundamental. So, who better

\footnotetext{
Abbreviations used in this paper: BMP, bone morphogenetic protein; ChAT, choline acetyltransferase; CNS, Central Nervous System; DG, dentate gyrus; ECM, extracellular matrix; EPO, erythropoietin; MMP, matrix metalloproteinase; N-CAM, neural cell adhesion molecule; NSC, neural stem cell; RA, retinoic acid; SGZ, subgranular zone; SVZ, subventricular zone; TIMP, tissue inhibitor of metalloproteinase.
}

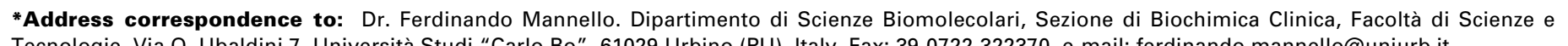
Tecnologie, Via O. Ubaldini 7, Università Studi “Carlo Bo”, 61029 Urbino (PU), Italy. Fax: 39-0722-322370. e-mail: ferdinando.mannello@uniurb.it 
than matrix metalloproteinases (MMP) could have a say in such an intriguing mechanism?

\section{Matrix metalloproteinases}

The world of proteolytic enzymes is populated by many families of exo- and endo-peptidases, among which there are serine, cysteine, aspartic and metallo-proteinases. This last class of enzymes is capturing a great attention as, from the discovery of its first member, just forty years ago, accumulating data show the biological importance of this ever growing enzyme family. MMPs have not only been characterised in vertebrates (in particular in humans), but also identified in several non-vertebrate organisms (Mannello et al., 2005b), such as the sea urchin embryo (Lepage and Gache, 1990), the Drosophila (Llano et al., 2000), and the hydra (Leontovich et al., 2000). Just to add a pinch of wonder to the amazing story of MMP, evolutionary studies suggest that MMPs (starting from a primordial point in their evolutionary history where they existed as single-domain proteins) underwent gene fusion processes generating multi-domain enzymes. In the course of time, an assembly of structural different domains occurred, taking place independently but going on in parallel manners; however, it seems that in some instances the evolutionary progress went back to front, as complex multidomain proteins generated simpler enzymes due to truncation in the gene sequence and loss of one or more domains (Massova et al., 1998; Mannello et al., 2005b).

Up-to-now, more than 25 MMPs have been identified and the distinctive characteristics of this subgroup of matrixins is their dependence on the zinc ion at the active site, the presence of the cysteine switch motif in the propeptide and the zinc-binding domain in the catalytic domain (Visse and Nagase, 2003; Nagase et al., 2006; Cauwe et al., 2007).

The main function of these enzymes is the remodelling and degradation of the extracellular matrix (ECM) which is composed of a complex mixture of insoluble molecules including collagens, laminins, fibronectins, entactin/nidogen and heparin sulphate proteoglycans. This capacity of degrading most of the components of the ECM scaffold, makes MMPs strong regulators and modifiers of the status of the extracellular environment (Mott and Werb, 2004; Cauwe et al., 2007). In this way, these proteinases may participate in many physiological events that require ECM breakdown and modification, such as cell migration, proliferation, morphogenesis, and apoptosis (Vu and Werb, 2000; Mannello et al., 2005a; Page-McCaw et al., 2007); on the other hand, they actively participate in pathological processes, such as cancer growth, metastasis and invasion (Egebland and Werb., 2002; Mannello et al., 2005c; Corbitt et al., 2007). However, this is not enough for MMPs; in fact their activity is not just limited to the plain degradation of extracellular proteinaceous components, but it goes much further. MMPs influence cellular functions in several different ways as they target non-matrix proteins which include other proteinases, proteinase inhibitors, clotting factors, chemotactic molecules, latent growth factors, growth factor-binding proteins, cell surface receptors and cell-cell adhesion molecules (McQuibban et al., 2000; McCawley and Matrisian, 2001, Zhang et al., (2006).

First of all, they can regulate cell proliferation facilitating and allowing the interaction between growth-suppressive or mitoge- nic factors and their cell-surface receptors, as they can cleave proteins associated with growth factors, or growth factors directly, resulting in the solubilization of the associated molecules (McCawley and Matrisian, 2001; Cauwe et al., 2007). These proteolytic enzymes are controlled by specific inhibitors that are also involved in the apoptotic phenomenon (Mannello and Gazzanelli, 2001). It is known that the basement membrane and the extracellular microenvironment mediate signals necessary for cell survival, and the breakdown of extracellular components, with the consequent degradation and loss of survival signals, leads to cell death (Frisch and Ruoslahty, 1997). Interacting with such a wide number of substrates in the ECM, makes MMPs ideal regulators of cell migration, as this process requires modification in cell-cell and cell-matrix adhesion, and the continuous degradation and remodelling of the extracellular matrix. MMPs may positively or negatively influence cell migration, as modifying directly the extracellular scaffold they can remove or cause the exposure of adhesion sites influencing cell attachment and migration, but they can also modulate cell migration through the release or inactivation of chemotactic signals (McQuibban et al., 2000; McCawley and Matrisian,, 2001; Cauwe et al., 2007). Moreover, MMPs regulate the availability of paracrine factors thus influencing the behaviour of several cell types; in fact they modulate the release of signalling factors either by inactivating them directly or by inactivating their soluble binding proteins (Sternlicht and Werb, 2001). It is clear that MMP substrates are not barely restricted to matrix components, but comprehend a wide number of nonmatrix proteins, allowing these proteolytic enzymes to abolish the normal biological function of their substrates and to form breakdown products which may be characterized by new biologic activity (Sternlicht and Werb, 2001; Hamano etal., 2003; Mannello et al., 2006a; Cauwe et al., 2007).

\section{Main characteristics of gelatinases}

MMPs are classified according to their substrate specificity, domain organization and sequence similarities, and can be divided into six groups, which include collagenases, gelatinases, stromelysins, matrilysins, membrane-type MMPs and other MMPs (Visse and Nagase, 2003). Among these classes of proteolytic enzymes, gelatinases generate increasing interest due to their involvement in an ever growing number of biological events, ranging from normal physiological processes to pathological conditions. This class of enzymes is composed of two elements, named gelatinase A, or MMP-2 (E.C. 3.4.24.24) with chromosome location $16 q 13$, and gelatinase $B$, also called MMP-9 (E.C. 3.4.24.35) with chromosome location 20q11.2-q13.1 (Overall, 2002). When considering the structure organization of these enzymes, it is clear that they share the distinctive characteristics of the MMP family, possessing in addition peculiar and specific elements that distinguish these two proteinases from the other components of the MMP family. Gelatinases have a multi-domain organization; MMPs are synthesized as pre-proenzymes, in fact they contain an $\mathrm{N}$-terminal sequence, called pre-domain or signal peptide, that is removed during translation and leads to the generation of proMMPs. Activation of these zymogens is therefore an important regulatory step of MMP activity. This N-terminal signal domain is followed by the pro-domain, which is essential for the latency and activation mechanism of all MMPs; it contains the cysteine switch motif reading PRCGXPD where an unpaired 
cysteine residue, through its bond with the catalytic zinc ion, maintains the enzyme in a latent zymogenic form. The enzyme reaches its fully active state when this bridge between the cysteine and the zinc ion is disrupted (Brinckerhoff and Matrisian, 2002). The prodomain consists of three $\alpha$-helices and connecting loops where the first loop between helix 1 and 2 is a proteasesensitive "bait region" (Visse and Nagase, 2003). The catalytic domain of gelatinases contains the highly conserved sequence present in all MMPs, with 5-stranded $\beta$-pleated sheets, three $\alpha$ helices, and connective loops, that create an overall spherical topology (Brinckeroff and Matrisian, 2002). This domain contains one catalytic zinc, one structural zinc and three calcium ions; it is characterized by three histidines that bind the zinc ion and a conserved methionine turn that lies under the active site zinc creating a base to support the structure around the catalytic zinc (Bode et al., 1993; Nagase and Woessner, 1999). Compared to the other members of the family, gelatinases have an additional insertion within their catalytic domain, formed by three head-totail cysteine-rich repeats, which are similar to the collagenbinding type II repeats of fibronectin; this additional domain seems to be involved in the binding and cleavage of substrates, as it binds to collagens, gelatin and laminin (Murphy et al., 1994; Shipley et al., 1996; Visse and Nagase, 2003). These fibronectin modules don't alter the overall structure of the catalytic domain as they turn outwards (Brinckeroff and Matrisian, 2002). These repeats are inserted between the fifth $\beta$-strand and the catalytic site helix; the structure of each fibronectin domain consists of two antiparallel $\beta$-sheets connected with a short $\alpha$-helix and stabilized by two disulfide bonds (Morgunova et al., 1999). Following the catalytic domain there is a hinge region, characterized in MMP-9 by a unique type $\mathrm{V}$ collagen-like insert at its end of unknown function. (Sternlicht and Werb, 2001). Finally, there is the Cterminal domain known as the hemopexin/vitronectin domain that is folded into a four-bladed propeller structure; the centre of the propeller contains one calcium ion and a chloride. This domain seems to be involved in some function of these MMPs such as the binding of substrates, and is also required for MMP-9 dimerization and proMMP-2 activation (Visse and Nagase, 2003).

Gelatinases derive their name from their capacity to degrade heat denatured collagen, or gelatine. Besides this substrate, gelatinases act also on other matrix components such as collagen type I, III, IV, V, XIV, decorin, elastin, laminin, fibrillin, myelin basic protein, osteonectin and vitronectin. Moreover, these enzymes don't proteolytically degrade only proteins belonging to the extracellular scaffold, but influence the activity of proteins such as fibrin, fibrinogen, IL1 $\beta$, ProTGF $\beta$, proTNF $\alpha$, plasminogen, thus revealing their many various characteristics and suggesting their multifaceted roles (Sternlicht and Werb, 2001).

\section{Gelatinase regulation}

For metalloproteinases, and in this case for gelatinases, they must be present in the right cell type and pericellular location, at the right time, and in the right amount, and, moreover, they must be activated or inhibited. The expression and activity of gelatinases may be regulated at several steps, such as transcriptional, posttranslational and protein level (via activators, inhibitors and localization to the cell surface) (Burrage et al., 2006; Mancini and Di Battista, 2006; Vincenti and Brinckerhoff, 2007; Yan and Boyd, 2007).
For what concerns the transcriptional regulation, even though most MMPs, among which MMP-9, are closely regulated at this level, MMP-2 is often constitutively expressed and controlled through a unique mechanism of enzyme activation (Strogin et al., 1995) and some degree of post-transcriptional mRNA stabilization (Overall et al., 1991). It has also been demonstrated that the basal expression of MMP-2, MT1-MMP and TIMP-2 is co-regulated, which reflects their synergic action during MMP-2 activation (Lohi et al., 2000). MMP gene expression is regulated by numerous stimulatory and suppressive agents, such as phorbol esters, integrin-derived signals, extracellular matrix proteins, cell stress, and changes in cell shape (Sternlicht and Werb, 1999). The expression of gelatinases is also regulated by cytokines and growth factors, including interleukins, interferon, EGF, KGF, NGF, VEGF and the extracellular matrix metalloproteinase inducer EMMPRIN (Fini et al., 1998). Many if these factors lead to the expression and/or activation of $c$-fos and c-jun products, which heterodimerize and bind activator protein-1 (AP-1) sites within MMP gene promoters (Sternlicht and Werb, 2001)

At the post-transcriptional level, gene expression can be regulated through the stability of mRNA in the cytoplasm. This can be mediated by several trans-acting factors such as RNA-binding proteins and microRNAs that interact with cis-elements located at many sites in the mRNA (Clark et al., 2008). The most frequent cis element is the AUUUA sequence which is often found in multiple copies at the 3? UTR of mRNA; binding of protein factors to these elements can stabilize or destabilize such mRNA (Garneau et al., 2007). mRNA transcripts can be stabilized by phorbol esters and EGF, or by PDGF, while can be destabilized by TGF- $\beta$ (Vincenti et al., 2001).

Even though almost all MMPs are constitutively secreted after their translation, in some instances, there may be secretory control. In particular, MMP-9 is synthesized by differentiating granulocytes, stored in specific granules of circulating granulocytes, and released after neutrophil activation by inflammatory agents (Hasty et al., 1990).

For what concerns the activation of latent MMP, Gelatinases, are secreted as inactive zymogens or proenzymes; the sulphydryl group of the unpaired cysteine which lies near the C-terminal end of the propeptide is the fourth ligand of the active zinc ion. For activation to occur, the propeptide has to be removed and the thiol group replaced by a water molecule that leads to proteolysis of MMP substrates The latent enzyme can be activated by proteinases, such as serine-proteases or also MMP or in vitro by chemical agents, such as thiol-modifying agents, oxidized glutathione, SDS, chaotropic agents, and reactive oxides (Mannello et al., 2005b, Ra and Parks, 2007). The activation may occur in more steps, as in a first moment, an exposed loop region between the first and the second helice of the propeptide gets proteolytically cleaved, and subsequently the destabilization caused by this removal allows further intermolecular modifications and processing to generate the fully active MMP (Nagase, 1997; Van Wart and Birkedal-Hansen, 1990). While MMP-9 activation follows the common laws of most MMPs, MMP-2 is refractory to activation by proteinases, such as serine proteinases, and shows a particular and unique activation mechanism which takes place on the cell surface and involves MT1-MMP and one of the four tissue inhibitor of metalloproteinase (TIMP), in specific TIMP-2 (Morgunova et al., 2002). ProMMP-2 forms a tight complex with 
TIMP-2 through hemopexin domain interactions with the noninhibitory C-terminal domain of the inhibitor. This complex formation is essential for proMMP-2 activation by MT1-MMP on the cell surface (Itoh and Seiki, 2005). The complex binds to an active MT1-MMP through the free N-terminal MMP inhibitory domain of TIMP-2, which orients the propeptide of proMMP-2 to an adjacent active MT1-MMP. Two MT1-MMP molecules interact with each other on the cell surface through their hemopexin domains, thus forming a tetrameric quaternary proMMP-2 activation complex; one MT1-MMP molecule acts as a receptor of the proMMP-2/ TIMP-2 complex and the other as an activator of proMMP-2. An excess TIMP-2 prevents this activation process by inhibiting the second MT1-MMP (Mannello, 2006a; Wang etal., 2000). ProMMP2 also forms a complex with TIMP-3 and TIMP-4 possibly in a similar manner. The proMMP-2/TIMP-4 complex interacts with MT1-MMP, but this complex is non-productive in terms of MMP2 activation (Bigg et al., 2001; Mannello, 2006b). The biological significance of the proMMP-2/TIMP-3 complex is not known.

The hemopexin domain of proMMP-9 also forms a tight complex with TIMP-1 and TIMP-3 through their C-terminal domains. ProMMP-9 in neutrophils partially binds to neutrophil gelatinase associated lipocalin-like molecule (NGAL) through an intermolecular disulfide bond (Kjeldsen, 1993). However, the biological significance of these complexes is not known, except that proMMP9/timp complexes are potential inhibitors of metalloproteinases.

One more way by which the activity of gelatinases is regulated, is via their pericellular localization, and specific mechanisms exist to confine or concentrate proteinases in the immediate pericellular microenvironment. MMP- 2 binds to integrin $\alpha \mathrm{v} \beta 3$ on the surface of angiogenic endothelial cells and invasive cancer cells (Brooks et al., 1996). On the other hand, latent proMMP-9 strongly binds to type IV collagen $\alpha 2$ chains on the surface of several cells (Toth et al., 1999), and activated MMP-9 binds to the cell surface hyaluronan receptor CD44 (Bourguignon et al., 1998).

\section{Endogenous gelatinase inhibitors}

MMP-2 and MMP-9 gelatinolytic enzymes are finely regulated by tissue inhibitors TIMP, which may control the proteolytic cascade in both physiologic and pathologic conditions (such as apoptosis, tissue remodelling, and cancer) (Mannello and Gazzanelli, 2001; Mannello, 2006b). The endogenous inhibitors TIMPs regulate Gelatinase activity, and for this reason changes in TIMP levels deserve attention as they directly influence and regulate MMP activity. TIMPs are expressed by several cell types and can be found in most tissues and body fluids. These are specific proteins belonging to a family of at least 4 members that reversibly inhibit MMPs forming a 1:1 stoichiometric complex that is resistant to proteolytic degradation. Studies on truncated TIMPs suggest that their $\mathrm{N}$-terminal region is the one responsible for the interaction with the active site of the proteinases (Murphy and Willenbrock, 1995). Not all TIMPs interact with gelatinases and regulate their activity in the same manner (Mannello, 2006b); in fact, proMMP-9 binds preferentially to TIMP-1 (in particular, the C-terminal domain of TIMP-1 binds the hemopexin domain of MMP-9), while proMMP-2 as discussed above, binds to TIMP-2, in this case influencing its activation (Howard and Banda, 1991; Wilhelm et al., 1989). Moreover, both proMMP-2 and proMMP-9 bind to TIMP-3 and the C-terminal domain of proMMP-2 can interact with TIMP-4 (Bigg et al., 1997; Butler et al., 1999).
Beside TIMPs, MMP-2 is also inhibited by a C-terminal fragment of the procollagen $\mathrm{C}$-terminal proteinase enhancer protein, and the proteolytic activity of MMP-2 and MMP-9 is downregulated by RECK, a GPI-anchored glycoprotein (Mott et al., 2000; Oh et al., 2001).

\section{Neural stem cells: the enigma is getting resolved}

CNS is constituted by specialized cell types such as neurons and glial cells (astrocytes and oligodendrocytes). Neurons have polarized and specialized processes, axons and dendrites, which propagate action potentials and make synaptic junctions with other neurons, which are the site of neurotransmitters release. Neuroglia and ependymal cells lack axons and dendrites. Neuroglia consists of astrocytes and oligodendrocytes. They are defined by their propensity to support other cells such as neurons with their dendrites, somata, axons and synaptic endings. Ependymal cells line the ventricular cavity, they are usually ciliated and generate monolayers of cuboidal or columnar epithelium, forming tight junctions at their apical surface. All of these cell types are generated during development from a common source, the neuroepithelial cell that originates in the early embryo in the neural tube (Lledo et al., 2006; Morest and Silver, 2003).

For a long time, the nervous system has been considered as a structure devoid of spontaneous cellular reconstitution properties, where the regeneration of damaged axons and the generation of new neurons seemed to be highly improbable (Cajal, 1913). In fact, until recently, the leading trait was that the mature CNS lacked regenerative capacity, and neurons in this organ were terminally differentiated and not replaced after death.

However, contrary to this long-held dogma, since early 60's several studies suggested that neurogenesis occurs throughout adulthood (Altman, 1962; Altman and Das, 1965; Kaplan et al., 1977; Paton et al., 1984; Reynolds and Weiss, 1992; Vescovi et al., 1993; Eriksson et al., 1998), and that neural stem cells (NSC) don't only exist in the developing mammalian nervous system, but also in the adult CNS of mammals, including humans (for a review see: Gage, 2000), indicating that the developmental processes of the brain may be never ending. Neurogenesis requires that newly formed immature neurons migrate to their final position and terminally differentiate sending out long axonal and dendritic processes integrating in the pre-existing neuronal circuits.

In the adult brain there are two regions where neurogenesis has been demonstrated to take place throughout life: these are the subependymal or subventricular zone (SVZ) of the later ventricle Doetsch et al., 1997; Doetsch et al., 1999) and the subgranular zone (SGZ) of the dentate gyrus (DG) in the hippocampus (Cameron et al., 1993; Gould et al., 1999). The SVZ can be considered as a residue of the embryonic neural tube, which persists throughout life as an actively mitotic area in the wall of the telencephalic lateral ventricles; during adult life, new neurons from this region migrate through the rostral stream into the olfactory bulb where they complete their differentiation process (Luskin, 1993; Lois and Alvarez-Buylla, 1994; Belluzzi et al., 2003: Merkle et al., 2007). Moreover, new neurons originating from the SGZ are continuously added into the granular cell layer of the DG (Van Praag et al., 2002; Cameron and McKay, 2001; Toni et al., 2007).

In addition to physiological stimuli, neurogenesis is also modu- 
lated by pathological conditions. A number of studies have shown that epileptic seizures, brain ischemia, and brain trauma increase neurogenesis (Bengzon et al., 1997; Liu et al., 1998; Braun et al., 2002; Dash etal., 2001; Nakatomy etal., 2002; Parent etal., 1997; Parent et al., 2002). Recently it has been shown that adult rat brain responds to cerebral ischemia increasing neurogenesis ipsilaterally to the infarcted area. SVZ newly formed neuroblasts migrate into the damaged site where they differentiate to mature neurons with characteristics of striatal medium spiny neurons indicating a partial replacement of damaged or dead cells and hence a possible contribute of neurogenesis to spontaneous recovery observed after stroke (Arvidsson et al., 2002; Thored et al., 2006; Zhang et al., 2007). Under in vitroconditions, and in the presence of specific growth factors, such as fibroblast growth factor 2 and/or epidermal growth factor, neural stem/progenitor cells isolated from both embryonic and adult brain regions (Temple, 1989; Lois and Alvarez-Buylla, 1993; Vescovi et al., 1993; Gritti et al., 1996; Davis and Temple, 1994; Doetsch etal., 1999; Johansson et al., 1999; Parmar et al., 2002; Qian et al., 1997; Reynolds and Weiss, 1992; Reynolds and Weiss, 1996), can proliferate and if plated on uncoated plastic surface form dividing clusters of cells called "neurospheres"; this mechanism of expansion represents an helpful culture method that allows to experimentally define the NSCs, to evaluate their multilineage potency and self-renewing capability (Weiss and Van der Koy, 1998). This method, starting from an heterogeneous primary culture, causes the death of committed or more differentiated mature cells, and the positive selection of the undifferentiated NSCs, which proliferate initially as adherent cells and attaching to each other, give rise to spherical clusters that float in suspension: the so called "neurospheres" (Studer, 2001). However, only a portion of cells maintains the characteristics of stem cells, while the rest undergoes differentiation; so a neurosphere is composed of NSCs, differentiating progenitors, and even differentiated neurons and glia, depending on the size and time culture of the neurosphere (Galli et al., 2003). The undifferentiated cells can be dissociated to form secondary spheres and thus expanded, or they can be treated to differentiate to generate neurons and glia (Reynolds and Weiss, 1992). Neurospheres culture is an interesting and useful tool to culture and measure neural stem cell properties even though cautions have to be used for assessing clonality, number and fate of stem cells (Singec et al., 2006).

NSCs isolated from human specimen, rather than foetal tissue, could be an appropriate source to the generation of neurons and glia suitable for the transplantation of specific cell types lost in different neurodegenerative diseases. Understanding the basic neural stem cell biology is crucial to establish appropriate protocols which permit the expansion and differentiation of human NSCs toward the desired cell types (Lindvall and Kokaia, 2005). In recent years, NSCs cultures from embryonic and adult human brain have been established. Human NSCs from different brain areas have been isolated and expanded as neurospheres by means of epigenetic immortalization strategy based on the continuous growth factors supply to the cultures (Carpenter et al., 1999; Kallur et al., 2006; Palmer et al., 2001; Svendsen et al., 1998; Vescovi et al., 1999), although alternative approach based on a combination of genetic and epigenetic immortalization strategies have been also used to generate clonal derived NSC lines. Interestingly several human NSC lines have been produced using the DNA sequence of the v-myc gene isolated from the avian myelocytic leukemia virus (Cacci et al., 2007; Flax et al., 1998; Pollock etal., 2006; Sah etal., 1997; Villa etal., 2000). Despite the concern about the nature and safety of genetically immortalized cell lines, different studies have shown that v-myc overexpression "functions" without transforming human NSC lines (for a review see: Navarro-Galve and Martinez-Serrano, 2006). Recently it has been demonstrated that NSC adherent lines can be established from either embryonic stem (ES) cells or from foetal or adult SVZ of mouse brain (Conti et al., 2005; Pollard et al., 2006; Bibel et al., 2004). Similarly, foetal human NS adherent cell lines have been isolated (Sun et al., 2008). These cells, after prolonged expansion, retain the ability to differentiate into neurons and astrocytes in vitro and upon transplantation in the adult brain. This culture procedure is particular suitable for avoiding spontaneous cell differentiation and for the maintenance of symmetrically expandable, apparently homogeneous adherent cultures, and represents a directly accessible system to study the effects of different experimental conditions on the stem cell state (Bain et al., 1995; Brustle et al., 1999; Conti et al., 2005; Pollard et al., 2006; Ying et al., 2003). Generation of human adherent NS cell lines might help to better understand some aspects of neural-developmental processes, such as self renewal, survival, migration and differentiation.

\section{Neural stem cell identity}

Even though the idea that adult neurogenesis does occur, the identity of neural stem cells is not yet exactly clear. According to the definition of stemness, stem cells are undifferentiated cells with the characteristics of proliferation, self-maintenance, production of differentiated progeny, and regeneration of injured tissue. It is now established that there are adult brain cells with the capacity of self-renewal and differentiation in vivoand in vitro, and that newly generated neurons have the capacity of migrating and integrating the pre-existing circuits of the CNS contributing to specific brain functions (Doetsch and Hen, 2005; Kempermann et al., 2004; Lie et al., 2004; Temple and Alvarez-Buylla, 1999). It has been proposed that the cellular diversity of the CNS is generated in a stepwise manner, as the multipotentiality of NSCs is mediated by the generation of cell-lineage restricted intermediate progenitors that produce only neurons (neuronal progenitors) and glial progenitors that produce only astroglial or oligodendrogial cells (Qian et al., 2000). However, the neurons generated in the adult CNS seem to be derived from several sources (Heins et al., 2002; Buffo et al., 2008; Belachew et al., 2003; Nunes et al., 2003; Morest and Silver, 2003).

The differentiation and lineage-commitment of NSCs are based on still undetailed mechanisms, something like "the dark side" of the CNS. Differently from the classical theory hypothesizing that neurons and glia generate from two separate branches of a lineage tree, the actual concept is that a common set of NSCs, can give rise to committed progenitors and terminally differentiated cells. Depending on the time of development, these cells may show neuroepithelial, radial glial or astrocytic characteristics with different and peculiar morphologies and markers (Noctor et al., 2001; Malatesta et al., 2000; Alvarez-Buylla et al., 2001; Gotz and Barde, 2005).

There are actually several hypotheses on the identity of the NSC, as many data show that multiple cell types with NSC 
characteristics have been characterized in the CNS. In the SVZ a complete turnover of the proliferating cells takes from 12 to 28 days, and about 30.000 new neuronal precursors are produced every day and migrate to the olfactory bulb (Craig et al., 1999). In the SVZ of the adult brain the three main cell types are A, B and $C$. The $A$ cells are migrating neuroblasts that proliferate and migrate from this region to the olfactory bulb. Astrocytes, that are organized into channels called glial tubes oriented along the anteroposterior axis, support the migration of NSC-generated neuroblasts (Loia et al., 1996). The C cells are intermediate, rapidly proliferating, transit-amplifying progenitors cells that give raise to the A cells. It has been proposed that astrocytes-like cells (B cells) in the adult SVZ, which line the border between the striatum and the lateral ventricle, behave like slow-dividing neural stem cells generating neuroblasts in vivo (Doetsch et al., 1999; Garcia et al., 2004). Considering the immature characteristics of SVZ astrocytes and the bipotent stem cell property of radial glial of the developing cortex, it is possible that the $B$ cells are the adult neural stem cells that generate $C$ and $A$ cells in vivo (AlvarezBuylla et al., 2001).

In addition to these cell types, there are the ependymal cells ( $\mathrm{E}$ cells) that line the ventricle lumen (Mendez-Otero et al., 2005). The wall of the ventricular system is made of a single layer of ependymal cells facing the lumen and a subventricular zone lying beneath this ependymal layer. An interesting work reports that even though both ependymal and subependymal cells both have proliferative potential, only subependymal cells display NSC features; subependymal cells have self-renewing capacity, as they can form secondary spheres in the presence of growth factors, and have also multipotential characteristics, as clonally derived spheres could produce neurons and glia after differentiation. On the other hand, the spheres generated from ependymal cells are not able to self-renew generating secondary spheres after dissociation, and can not produce neurons, but only glial fibrillary acidic protein-positive cells, indicating that ependymal cells are differently regulated with respect to subependymal cells (Chiasson et al., 1999). However it has also been suggested that possible sources of NSCs may reside in the neuroepithelium of the adult nervous systems; cells such as the ciliated-ependymal cells, represented by a homogeneous cell population, may have the right requisites for being neural stem cells as they are very similar to embryonic neuroepithelial cells from which they derive. Ependymal layer cells seem to express the intermediate filament protein nestin, which has been characterized as a marker for neuroepithelial cells and CNS stem cells in vivo and in vitro, and Notch 1, another marker for immature neural cells. Interestingly it has been reported generation of NSC from all regions of the nervous system containing extension of the ventricular system including the spinal cord, which does not contain a (SVZ) (Weiss et al., 1996). Two independent studies reported data indicating that ependymal cells are NSC (Johansson et al., 1999; Coskun et al., 2008). In the hippocampus, the (SGZ) progenitor cells divide along the border between the hilus and the granule cell layer where immature neurons migrate and further differentiate (Seri et al., 2001). It has been proposed that adult DG contain neuronal progenitor cells with limitated self-renewal capacity, whereas stem cells reside in the hippocampus adjacent regions of subendyma (Seaberg and van der Kooy, 2002). However, a study from Palmer and colleagues suggests the existence of multipontent neural stem cells with considerable in vitro self-renewal capacity in the adult hippocampus (Palmer et al., 1997). Recently, the multipotentiality and self-renewal capability of Sox-2 positive NSC in the adult SGZ have been demonstrated in vivo (Suh et al., 2007). In this site, SGZ astrocytes generate intermediate progenitors, which mature locally into granule neurons of the dentate gyrus sending out axonal projections and dendritic arbours (LLedo et al., 2006; Markakis and Gage, 1999; Toni et al., 2007).

\section{Neural stem cell niche}

Now that the existence of stem cells in the adult CNS has been established, a challenge is to try to understand the mechanisms that in some way, regulate and influence the fate of NSCs. NSCs are in continuous contact and interact with their surrounding environment, occupying a specific niche in the adult brain. In the two areas of the brain where adult neurogenesis has been found to occur, neural stem cells occupy niches formed by both astrocytes, that support the differentiation into neurons, and endothelial cells, that help NSCs to renew themselves; it has been showed that neurogenesis is intimately associated with a process of active vascular remodelling, suggesting that adult neurogenesis occurs within an angiogenic niche (Shen, 2004). It is possible that plasticity in the adult Central Nervous System may be influenced by mesenchyme-derived cells and circulating factors (Palmer et al., 2000; Palmer, 2002). The specialized properties of the vasculature in the SVZ NSC niche and the tight association between NSC and endothelial cells have been recently demonstrated (Shen et al., 2008; Tavazoje et al., 2008).

However, mammalian NSCs are not passive elements, but rather, there is a bidirectional communication between the intrinsic programmes controlling different neurogenic phases, and the extrinsic informations produced by the external environment. Since multipotent precursors cells can generate neuronal and glial cells, cell proliferation of stem cells and their progeny must be highly and precisely controlled. Most of the extrinsic factors that regulate neurogenesis act in a complex manner, as they specifically determine stem cell fate in their respective niches. NSCs are kept in an undifferentiated state by the components of the Notch signalling pathway, while positive regulators lead to the differentiation of NSCs: the synergistic signalling of the gp130/JAK/Stat3 and bone morphogenetic protein (BMP) causes NCSs to differentiate into astrocytes (Itoshi et al., 2002; Nakashima et al., 1999; Song et al., 2002; Yamamoto et al., 2001). In fact, the BMP family leads NCSs towards a glial determination, probably making them adopt the default pathway that brings to astrocyte formation (Lim, 2000). Interestingly, it has been reported that secreted glycoproteins WNTs affects nervous system development (Ciani and Salinas, 2005) and exert influence on adult neurogenesis affecting both neuronal fate specification of NSC and neuroblasts proliferation (Lie et al., 2005).

Neuronal commitment is also regulated by the neuronal bHLH transcription factors including Mash1, Neurogenin, and the Math family, and it seems that the determination into a specific cell lineage causes the exclusion and suppression of alternative cell lineage commitments (Lim, 2000; Mizuguchi et al., 2001). In particular, neurogenin 1 is secreted by astrocytes and promotes the differentiation of adult NSCs through the prevention and exclusion of glial determination (Nieto et al., 2001; Ueki, 2003). An antagonist of BMP is noggin, which is secreted by ependymal 
cells, and shifts stem cell from a glial fate to a neuronal one (Lim, 2000; Ueki, 2003; Fan et al., 2004). Although the roles are not well understood, important functions in controlling proliferation are held by adhesion molecules: neural cell adhesion molecule (NCAM) enables hippocampal neurogenesis proliferation and the differentiation of neuronal cell (Amoureux et al., 2000), while CD24, a highly glycosylated molecule expressed in both neurogenic areas, influences the increase and the decrease in the number of the proliferating cells (Belvindrah et al., 2002). However, the fate determination of NCSs is also influenced by the context in which these cells are found, such as their developmental stage and the location in the CNS. Environmental modifications influence in a direct manner the production, migration, maturation, differentiation and survival of NSCs; moreover, various extracellular signals, mediated by cytokines, neurotransmitters, growth factors, as well as by direct cell-cell and cell-matrix contacts, influence the determination of NCSs commitment, demonstrating that these signals have a role in the fate decision of endogenous NCSs (Lledo et al., 2006; Okano, 2002). It has been demonstrated that brain-derived neurotrophic factor stimulates hippocampal proliferation (Katoh-Semba, 2002), and ciliary neurotrophic factor, heparin-binding epidermal growth factor, basic fibroblast growth factor 2, insulin growth factor 1, transforming growth factor and vascular endothelial factor increase either dentate gyrus or SVZ proliferation (Aberg, 2003; Cao, 2004; Craig, 1996; Emsley and Hagg, 2003; Jin, 2002; Jin, 2003a; Jin, 2003b). Also hormones are implicated in nervous system development; corticosteroids, have a say in hippocampal neurogenesis (Cameron and Gould, 1994), while thyroid hormones are implicated in neurogenesis in the SVZ (Lemkine, 2005). All these factors contribute to the creation of a specific and peculiar environment in which NSCs differentiate within specialized niches that help maintain the multipotential and self renewal characteristics of NSCs and contribute to fate determination (Temple, 2001). What is important in this cross talk between NSCs and the external environment is the interaction with the extracellular matrix (ECM) that forms the NCS niche. This interaction is mediated by the cell surface receptors integrins that are involved in processes such as proliferation, survival, migration and differentiation and recent studies demonstrate that human neural precursors express high levels of integrin subunits which might be considered as useful markers for NSC isolation (Hall et al., 2006). An important element that contributes to control several steps of adult neurogenesis in specialized niches is represented by glia, and in particular by astrocytes, which are involved in proliferation, commitment, migration and integration of the neural progeny into the intricate CNS network. Astrocytes have long been known for their role of supporters of neural cells and identified as regulators of local microenvironments (Nedergaard et al., 2003), but recently astrocytes have gained attention due to their multiple and previously not fully appreciated roles (Ullian et al., 2004). In fact, as they are abundantly present in the neurogenic niches, providing physical support and contributing to cell-cell signalling, it seems that neuronal production in the adult CNS may be at least in part regulated by distinct properties of astrocytes (Song et al., 2002). It has been suggested that astrocytes are involved in such processes as stem cell maintenance, activation and self-renewal, neuronal fate specification, neuronal maturation, migration and nerve guidance, and finally, synaptic integration (Ma et al., 2005). Under physiological conditions astrocytes are in fact able to express and secrete membrane-associated and soluble molecules, such as cytokines, growth factors, and neurotransmitters (Ridet et al., 1997), and as they are tightly associated with synapses, they regulate synapse formation and maintenance (Christopherson et al., 2005). In this manner, astrocytes may act as finely regulated sensors of the external microenvironment, ready to capture any modification and to provide signals that regulate adult neurogenesis. Recent finding have also indicated microglia, the macrophage population of the brain parenchyma, as important cellular element implicated in the regulation of NSC properties, positively contributing to hippocampal and SVZ neurogenesis (Walton et al., 2006; Ziv et al., 2006). Controversial is the role played by microglia in the regulation of NSC properties under pathological condition (Monje et al., 2003; Ekdahl et al., 2003; Battista et al., 2006; Butowsky et al., 2005; Cacci et al., 2008). All these reports emphasize the importance of the extracellular environment in the decisionmaking events of NSCs.

\section{MMPs: at the scene of the crime again?}

The MMP system takes part and contributes to many aspects of the brain development. Many processes including, cell migration, axonal sprouting, neuronal differentiation and plasticity, could be modulated by gelatinases during brain development, maturation (Figure 1). The development/remodelling of neuronal connections, and cell invasion depend on modifications of the extracellular environment and on the presence of matrix and nonmatrix molecules, such as cell adhesion molecules; in particular neuronal cell surface adhesion molecules, expressed at high levels by a wide number of developing neurons and axons, are involved in neuronal morphogenesis contributing to neurite outgrowth in response to guidance cues (Anelli et al., 2007; Beggs et al., 1994; Martini, 1994), underlining the importance of the capillary regulation of extracellular components and of the processing of molecules involved in signalling cascades in the differentiation pathway of NSCs.

\section{Migration, axonal outgrowth and myelinogenesis}

MMPs are implicated in various processes involved in CNS development, such as migration of precursor cells, axonal outgrowth and myelinogenesis. In accordance with the well known role of MMPs in degrading the extracellular microenvironment, gelatinases might regulate the migration of different neural cell types to their final destination. For example, in vitro studies suggested that MMP-2 but not MMP-9 is a key enzyme for astrocyte migration (Ogier et al., 2006). There is increasing evidence for the involvement of MMPs in neurite elongation and axonal growth, where a proteolytic activity may be present at the tip of the neuronal extending cones. Various studies reported that the expression of both MMP-2 and - 9 was increased in neuroblastoma cells (Anelli et al., 2007) and in dorsal root ganglion neurons under the influence of inducers of differentiation and axonal outgrowth, such as nerve growth factor and retinoic acid (Chambaut-Guerìn et al., 2000). In particular choline acetyltransferase (ChAT) transfected murine neuroblastoma cells which synthesise acetylcholine and show enhancement of several neurospecific markers and fiber outgrowth, were studied for the MMP regulation (Anelli et al., 2007). Zymography of non 
transfected culture medium revealed no gelatinolytic activity, whereas ChAT-transfected clone culture medium contained both MMP-2 and MMP-9 and higher expression levels for both genes were observed in ChAT transfected cells suggesting a possible correlation between fiber outgrowth and MMP expression (Figure 2).

In vitro studies demonstrate that MMPs may regulate the migration of axons and their behaviour through the cleavage of the ectodomains of guidance cues and their receptors, abolishing or activating signalling pathways (Chambaut-Guerìn et al., 2000; Galko and Tessier-Lavigno, 2000; Hattori et al., 2000). It seems possible that MMP-2 degrades and inactivates the neurite-inhibiting activity of chondroitin sulphate proteoglycans present on nerves, revealing the hidden laminin which allows neurite outgrowth (Zuo et al., 1998). The remodelling of the ECM and thus the role of MMPs is necessary in the initial steps of myelination, where oligodendrocytes extend several processes from their soma that enwrap axons forming myelin layers. The initial expansion of these processes is enormous and may need extensive remodelling of the ECM; moreover, oligodendrocyte process extension requires an appropriate microenvironment containing growth factors and ECM molecules, and a cross-talk with axons for the formation of myelin. In accordance with the important role held by the extracellular system, MMPs facilitate process extension of oligodendrocytes in the CNS and in particular it has been demonstrated that myelin formation in the developing mouse optic nerve is correlated to increased MMP-9 levels (Oh et al., 1999). Moreover, increasing the outgrowth process in adult brainderived oligodendrocytes through factors known to stimulate extension, led to the enhancement of MMP-9 expression while it was blocked either by TIMP-1 or by an antibody specific for MMP9. These in vitro studies showed that gelatinolytic activity occurs at the tip of the advancing processes, suggesting that MMP-9 regulates the interaction of the advancing tip of oligodendrocytes with the external cues (Oh et al., 1999). The need of MMPs is demonstrated by the data showing that there is an increase in the expression of MMP-9 in parallel with the enhanced process extension of human cultured oligodendrocytes in the early developmental stages, and that the inhibition of MMP synthesis blocked oligodendroglial process extension (Oh et al., 1999; Uhm et al., 1998). The role of MMP-9 for myelin formation, during remyelination after injury and normal ontogeny, is further established as myelination in the corpum callosum of mice deficient for this enzyme is very reduced compared to wild type mice (Larsen et al., 2006). An

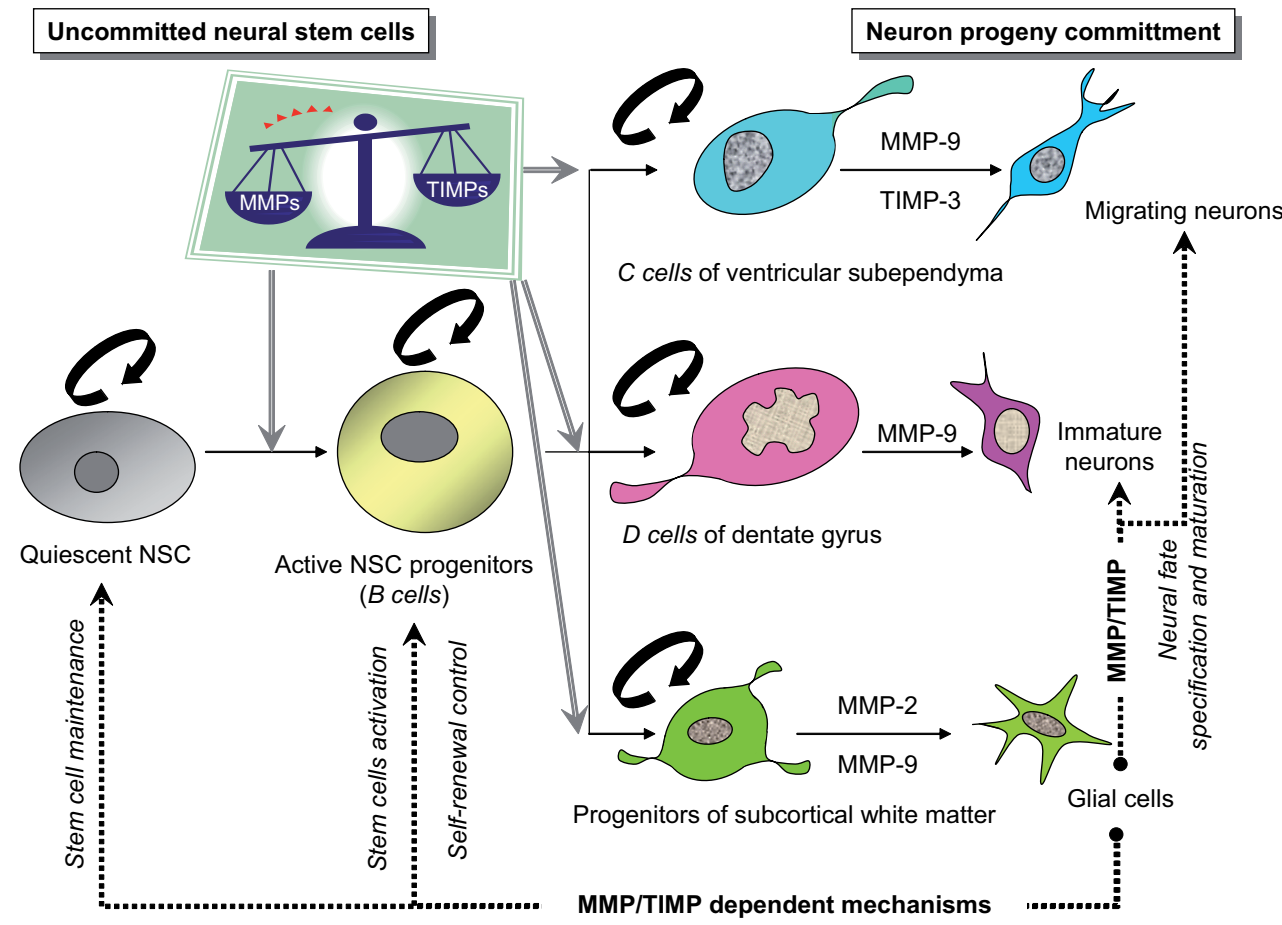

Fig. 1. Schematic representation of neural stem cell development in the adult brain and its regulation by glia through MMP-and TIMP-dependent mechanisms. The cell lineage begins from the ventricular zone of temporal lobe in which quiescent adult neural stem cells to active NSC progenitors (B cells); these cells can generate at least three populations of potentially neurogenic progenitors, of both neural and glial lineages. The shifting of direction of NSC differentiation/evolution is an essential step of neural stem cell plasticity that may be finely regulated by several proteinases belonging to the matrix metalloproteinase family, acting on extracellular, nuclear matrix proteins, and bioactive molecules. The active $B$ cells give rise to three different types of neural progenitor cells: C cells of ventricular subependyma; D cells of the subgranular zone of the dentate gyrus; and white matter progenitor cells of the subcortical parenchyma. Each transit-amplifying pool might then give rise to differentiated progeny appropriate to their location, including mature neurons (A cells in the olfactory subependyma), immature neurons (in the dentate gyrus of hippocampus), and glial cells loligodendrocyte and astrocytes in white matter). Multiple aspects of adult NSC development are influenced by glial cells which may regulate through a specific expression of both MMPS and their tissue inhibitors TIMPs the 1) stem cell maintenance, activation and self-renewal; 2) neural fate specification and maturation; and 3) migration, nerve guidance and synaptic integration. The proteolytic activity of MMPs and the anti-proteinase action of TIMPs are responsible for the differentiation hierarchy of human adult neural stem cells in both the uncommitted multipotent NSC (which has the potential for self-renewal and giving rise to a less potent precursor cell population via asymmetric cell division) and in the committed neural progeny (which shows the lowest level of stemness and a more restricted differentiation potential, via symmetric cell division). During adult NSC differentiation, transcriptional and phenotypic modifications increase, whereas proliferative potential progressively decreases, concomitantly with limited differentiation potential. It is known that several MMPS and TIMPs play crucial roles and functions during the terminal stages of NSC progenitor differentiation into mature neural and glial phenotypes. Because molecular studies have provided evidence that both MMP and TIMP genes are present in multipotent NSCs, the finely coordinated MMPITIMP balance may play a key role in self-renewal as well as in the precursor and progenitor differentiation of human adult NSCs. 
interesting evidence is that gelatinolytic activity has been found to be uniformly distributed not only along the oligodendrocyte processes, but also along their soma; even though the localization on the tip of extending processes may be explained by oligodendrocyte outgrowth, the presence of gelatinolytic activity on the soma may suggest that MMPs can release growth factors that are attached to the ECM, promoting oligodendrocyte survival (Oh et al., 1999).

A common method to study the differentiation and the development of CNS in vitrois by using neuroblastoma cell lines. It has been previously demonstrated that retinoic acid (RA), known to have a morphogenetic role in the nervous system pattern organization during embryonic development, induces human neuroblastoma cell lines to differentiate into a neuronal phenotype favouring neurite outgrowth and changing the distribution of the structural proteins (Chambaut-Guerìn et al., 1995). This neuroblastic cell type, with biochemical features of neuronal cells which differentiate toward a neuronal phenotype upon RA treatment, constitutively expresses MMP-2, whereas MMP-9 expression is inducible in response to RA exposure. This expression is linked to the RA-induced phenotypic differentiation of the neuroblastoma cell line to neuron-like cells. Moreover, the differentiation process is characterized by neurite extension and acquisition of cell polarity, due to modification in the distribution of the structural proteins tubulins and neurofilaments. The increase in MMP-9 was seen at both the mRNA and protein levels, in concomitance with the arrest of neuroblastoma cell proliferation and with its differentiation into neuron-like cells. Moreover, a time correlation between the progressive increase of MMP-9 expression and neuronal differentiation was found as MMP9 was located at the outgrowing neuritis during the early time of RA exposure and in an extensive neuritic network at later times (Chambaut-Guerìn et al., 2000).

\section{Gelatinases in neural development and differentiation}

Involvement of gelatinases can be found in processes occurring during the morphogenesis of the cerebellar cortex, as this stage of the nervous system development depends on intrinsic genetic programs as well as orchestrated cell-cell/cell-extracellular matrix interactions; MMPs in general regulate diverse neuronal functions including migration, process extension. MMP-2 and -9 in particular are expressed in the developing cerebellum (Luo, 2005). This functional involvement of gelatinases can be seen during rat cerebellar ontogenesis which is characterized by postnatal directional migration, differentiation, and synaptogenesis with a precise spatiotemporal order. Gelatinases, thanks to their finely regulated proteolytic activity, may determine the hierarchy of the mechanisms involved in brain development and plasticity. During cerebellar development, MMP-2 and -9 show a differential and precise spatio-temporal pattern of expression influencing in a precise manner alterations of the ECM. In particular, MMP-2 showed to be constantly present during postnatal development, while MMP-9 was present at higher concentration in early stages of development, localized with migrating granular cell precursors of the external granular layer, and also seemed to be expressed in processes identified as Bergmann glial fibers, dendrites and growing Purkinje cells. MMP-9, might influence the migration of
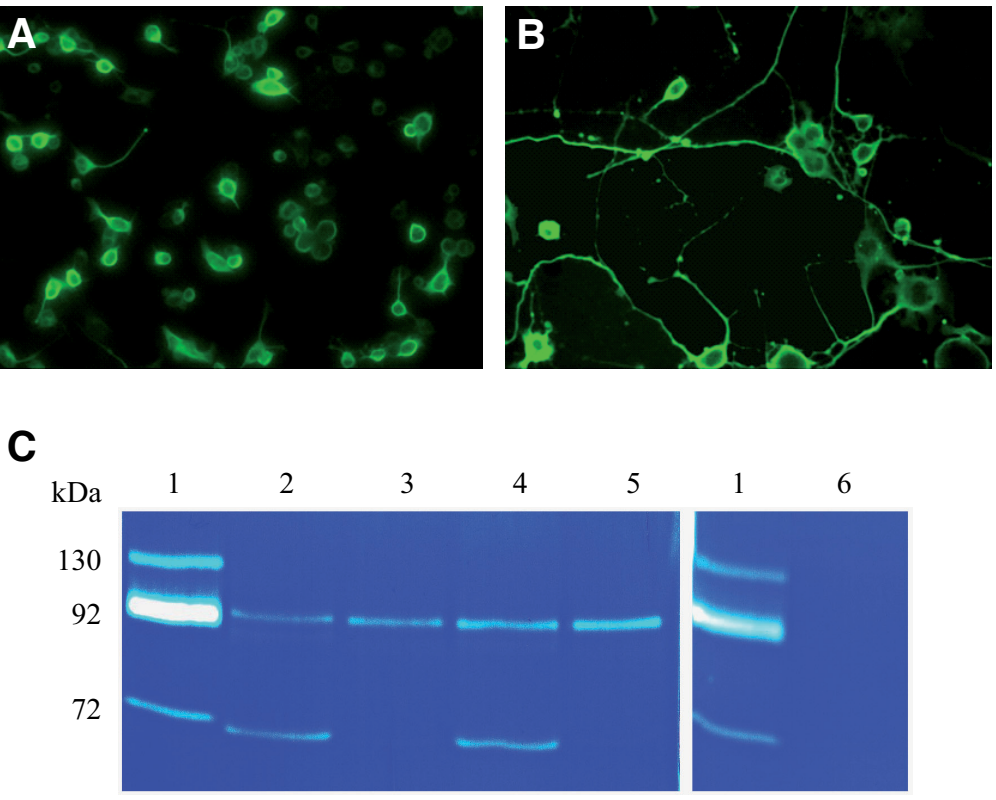

Fig. 2. Immunostaining for $\beta$ III-tubulin of N18TG2 neuroblastoma cells and ChAT-transfected clone, and analyses of gelatinolytic activities of matrix metalloproteinases identified in culture medium. (A) N18TG2 cells show a round morphology and little fiber formation. (B) N18TG2 neuroblastoma cells transfected with a construct for choline acetyltransferase instead display an increased ability to grow longer fibers (C) The zymogram of all gelatinase forms in peripheral blood, used as control, shows MMP-9 of 130 and $92 \mathrm{kDa}$, and MMP2 of $72 \mathrm{kDa}$ (lane 1). The zymographic profile of gelatinases found in the medium of 2 different clones isolated from ChAT-transfected N18TG2 cells reveals the 92 Da form of MMP-9 and the $66 \mathrm{kDa}$ form of MMP-2 (lanes 2 and 4). When the same clones are cultured in the presence of atropine, a muscarinic receptor antagonist which inhibits the action of the acetylcholine produced by the transfected clones, only the MMP-9 form at $92 \mathrm{kDa}$ is detected (lanes 3 and 5). The analysis of the zymographic pattern of the parental cell N18TG2 medium revealed no gelatinolytic activity (lane 6).

cerebellar cell precursors through local proteolysis and modification of cell signalling (Vaillant etal., 1999). Its expression is spatiotemporally related to granule cell migration, axonal outgrowth and induction of apoptosis (Vaillant et al., 2003); the decline in its activity correlates with a decreasing amount of migrating progenitor cells, mainly from the external granular layer of the cerebellum (Komuro and Rakic, 1998).

Differently from MMP-2, MMP-9 mRNA and protein expression have been found in the hippocampus, cerebellum and cortex, mainly in neurons, in cells bodies and also in dendrites (Dzwonek et al., 2004). However, MMP-9 expression, even though limited, has been revealed in glia, in particular in astrocytes and microglia (Dzwonek et al., 2004). MMP-9 expression seems to be spatiotemporally correlated with cerebellar granule migration during postnatal development, indicating that this gelatinase participates in regulating precursor cell migration and apoptosis in the developing cerebellum (Martini, 1994). The importance of MMP9 in the CNS is also indicated by the reports showing that upregulation of this enzyme coincided with the maximal extension of the transient cerebellar external granular layer, which is a marker of neuronal progenitor proliferation and migration (Ulrich et al., 2005). Moreover, MMP-2 and -9 have also been found to control process extension and synaptic plasticity in the development of 
the cerebellar cortex, highlightening the importance of finely modifying and regulating cell-cell and cell-matrix interactions and evidencing that these enzymes may hold key roles in the maturation of neural cells (Anelli et al., 2007; Beggs et al., 1994; Chambaut-Guerìn etal., 2000; Frollichsthal-Schoeller etal., 1999).

The localization of MMP-9 to the hippocampal dentate gyrus and its up-regulation under certain circumstances that require modifications of cell interactions, suggests that this proteinase is involved in synaptic plasticity (Dzwonek et al., 2004). A very interesting data helps understand the link between MMP expression and neuronal plasticity. It is in fact known that the transcription factor AP-1 (a dimer made of Jun or Jun and Fos) is tightly involved in regulating the expression of a wide number of MMP genes, in particular of MMP-9. In many instances neuronal cell surface receptors bound to specific ligands and affect the function of AP-1. In the brain a transient activation of AP-1 is strongly correlated with neuronal plasticity (Kaczmarek et al., 2002). Moreover, it has been demonstrated that plasmin, tissue and urokinase plasminogen activator, all involved in MMP activation, are implicated in neuronal plasticity phenomenons (Madani et al., 1999; Yoshida and Shiosaka, 1999). Interestingly, a similar important role for MMP-2 in neuronal plasticity has also emerged because an increase in the activity of MMP-2 correlates with functional plastic recovery during cortex projection formation to the hippocampal dentate gyrus (Dzwonek et al., 2004). MMP-2 has also been detected at the mRNA and protein level in various brain regions, and it seems to have preferentially an astroglial origin; moreover, it has been found also in some cortical neurons and in the cerebellum (Dzwonek et al., 2004). In fact, in the developing rat cerebellum, MMP-2 is mostly present in premigratory progenitors of the deep external granular layer and in Purkunje cells (Ayoub et al., 2005; Ulrich et al., 2005), while in the adult rodent CNS, it is found mainly in astrocytes (Azklarczyk et al., 2002). MMP-2 expression has been positively correlated with the thickness of the cerebellar external granular layer which might suggest its involvement in axonal outgrowth and synaptogenesis (Duchossoy et al., 2001; Zuo et al., 1998), and its presence in premigratory progenitors of the deep external granular layer demonstrates its role in the migration of these progenitors into the inner granular layer (Ayoub etal., 2005; Ulrich et al., 2005). In vitro studies indicate that this gelatinase is produced by astrocytes, microglia, oligodendrocytes and also neurons (Dzwonek et al., 2004). Activated microglia release MMP-9, and various cytokines strongly stimulate the expression of both MMP-2 and MM-9 in rat astrocytes (Gottschall and Deb, 1996). Further interesting in vitro studies revealed that MMP-2 is expressed by astrocytes and is tightly involved in their migration, being constitutively present in these cells. It is interesting to recall that inhibition of migration due to MMP inhibitors led to modifications in cell morphology and in the intercellular organization of the actin cytoskeleton. Moreover, inhibition caused a modification in the distribution of MMP-2 at the migration front which is focalized in untreated cells, and that after inhibition became diffuse and internalized, suggesting a link between the actin cytoskeleton and MMP-2. This study may be sustained by the fact that MMP-2 co-localizes with beta1-integrin at the migrating tip of astrocytes, making beta1-integrin the possible link between pericellular matrix degradation due to MMP-2 and the actin cytoskeleton (Ogier et al., 2006) and underlining the importance of the cross-talk between cells and the
ECM in the regulation of cell motility, growth, and differentiation. In a model of murine olfactory epithelium degeneration it has been shown that changes in MMP-2 expression are associated with specific phases of olfactory cell neurogenesis, as it can be assessed by the analysis of markers for immature developing neurons such as growth associated protein (GAP-43). In particular, immunohistochemical studies revealed that MMP-2 localizes to the basal and immature cell layers near the basement membrane (Tsukatani et al., 2003). MMP-2 was also observed along the surface of axon processes associated with newly differentiated neurons and in the deep layer of the lamina propria, providing evidence that MMP-2 activity may be associated with the outgrowth of axons and the unsheathing cells that surround olfactory nerve bundles (Tsukatani et al., 2003).

The expression and regulation of MMPs in neuroectodermal precursor cells has been evaluated in neuroepithelial stem cells isolated from human embryonic CNS stem analyzing the changes in MMP expression that occur when these cells differentiate into neurons and glia. First of all human undifferentiated CNS stem cells and differentiated progeny showed to express MMP-2. Moreover, the enzymatic activity of MMP-2 and the protein itself was detected in the human CNS stem cell progeny that had differentiated into neurons and glia, and a decrease in MMP-2 levels was found in differentiated cultures respect to undifferentiated ones (Frolichsthal-Schoeller et al., 1999). Moreover, the expression of MMP-2 could be associated not only with stem cells, but also to glial fibrillary protein-immunoreactive astroglia and to $\beta$-tubulin immunoreactive neurons.

\section{Gelatinases in brain injury}

It has been reported that the two zones involved in active neurogenesis, the SVZ and the hippocampal SGZ, promptly respond to different brain injuries with augmented neurogenesis. Middle cerebral artery occlusion for example increased the production of newly formed immature neurons which migrate to the damaged site (Arvidsson et al., 2003). Data from Lee and colleagues suggest that MMPs are involved in neuroblast migration; in fact, inhibition of MMPs by GM6001 clearly suppressed the neurogenic migratory response induced by stroke. In particular, it has been demonstrated that MMP-9 is a key protagonist in mediating the neurogenic response in the SVZ, allowing neuroblasts migration (Lee et al., 2006). This data indicate MMPs as a possible target to modulate self-repair brain mechanisms and hence enhance neurogenic recovery after stroke insult. However it is uncertain if neuroblast migratory inhibition is a direct consequence of the GM 6001 effects on matrix modulation per se or a secondary event due to a reduction in the brain inflammation and for example in the release of chemokines from activated glial cells. MMPs mediate neuroinflammation it is worth mentioning (Rosenberg, 2002; Yong et al., 2001).

It is well known that angiogenesis and neurogenesis are coupled process (Palmer et al., 2000). Recently it has been shown that erythropoietin (EPO) administered intraperitoneally enhances angiogenesis and increase the number of DCX positive cells in the ischemic boundaries (Wang et al., 2004). By using an in vitro approach it has been suggested that erythropoietinactivated endothelial cells release MMP2 and MMP9 and promote neural progenitor cell migration. It is tempting to speculate that increased number of neuroblasts recruited to the damaged site 
after stroke in EPO administered animals is due to an augmented released of MMP that contribute, probably together to several other factors including SDF1 (Thored et al., 2006), by matrix remodelling to create a permissive milieu for neuroblasts migration.

On the basis that the migration of newly formed cells is a fundamental feature in regenerative processes of the brain following injury and that MMPs are certainly involved in cell migration control, could be of crucial importance understand mechanisms presiding over their regulation. It has been investigated if inflammatory cytokines, widely released from glial cells typically activated in different neurodegenerative disease, modulate the expression of these proteases in neural precursors during repair mechanisms. Interesting results showed that TNF- $\alpha$ or INF- $\gamma$ significantly increased the levels of secreted proMMP-9; moreover, both cytokines enhanced pro and active MMP-2 protein levels in neural precursor cells, while the anti-inflammatory cytokine IFN- $\beta$ reduced the expression of both gelatinases. It seems that MMP-9 is regulated mainly at the mRNA level, while MMP-2 activity is regulated at the post-transcriptional level (Ben-Hur et al., 2006).

Neurogenesis and angiogenesis could contribute to repair after brain injury as suggested for stroke animal models. However spontaneous recovery after stroke can probably reflect also post ischemic reorganization of the spare neurons and glial cells. MMPs could have a crucial role in neuronal plasticity since they remodel all components of extracellular matrix. MMPs modify and regulate all components of the $\mathrm{ECM}$, they contribute to dendritic and axonal elongation as well as blood vessel formation (Kaczmarek et al., 2002; Pepper, 2001). In accordance to these roles attributed to MMPs during stroke recovery (Yong et al., 2001), in an animal model of cerebral ischemia, MMP-9 was found to be co-localized with neurons and astrocytes in the peri-infarct cortex and correlated to neurovascular remodelling evidencing its functional importance in the repair of damaged tissues (Zhao et al., 2006).

\section{Future perspectives}

Adding to the already surprising finding that NSCs exist in the adult human brain and provide a regenerative ability to the adult brain, we now add the interesting role of MMPs in the differentiation, migration, and survival of these neural precursors. Starting from the knowledge pointing to the connection of MMPs to several CNS topics (such as migration, axonal outgrowth, myelinogenesis, development, differentiation, and repair) (excellently reviewed in Yong et al., 2001), the novelty and importance of gelatinase function in neurogenesis or related functions is in its infancy and represents a promising field of research (Taupin and Gage, 2002; Mendez-Otero et al., 2005). Although the actual presence of scattered data about MMP connections to neurogenesis (Merkle and Alvarez-Buylla, 2006) does not allow a clear discussion of the reasons why this connection would make sense, the roles and functions of Gelatinases in neural stem cell biology (Mannello et al., 2006a) open new frontiers on a fine regulation of proteolytic cascades involved in neurogenesis and on how MMPs control neural stem cell fate (Agrawal et al., 2008). To strengthen the hypothetical connections, growing evidences highlight the crucial involvement of MMP activities in neural plasticity and during neurogenesis (Milward et al., 2007; Ethell and Ethell, 2007). In fact, the regulation of neurogenesis and oligodendrogenesis by MMPs (Agrawal et al., 2008) and TIMPs (Jaworski and Perez-Martinez, 2006) during CNS differentiation and development may be directed the proteolytic cleavage of several proteins that have been recognized as MMP substrates (e.g., brevican, tenascin- $\mathrm{R}$, laminin, pro-brain-derived-neurotrophic factor, ephrin, and cadherins) (Ethell and Ethell, 2007) and that play important roles in synaptogenesis, synaptic plasticity, longterm potentiation, normal brain functioning including learning and memory (Milward et al., 2007). Moreover, MMPs and TIMPs have been suggested as components of the neurogenic signaling cascade that play a role in the transition from proliferation to neuronal differentiation (Jaworski and Perez-Martinez, 2006), also favouring the modification of extracellular matrix during migration of neuroblasts (Bovetti et al., 2007) and inducing exogenous progenitor cells to promote the neural regeneration (Zhang et al., 2007).

Although MMPs and TIMPs play a role in synapses by regulating synaptogenesis and synaptic strength and plasticity, they are also recognized as proteinases expressed and developmentally regulated in both neuron and glial cells under normal physiological conditions (Ethell and Ethell, 2007). Higher MMP expression and activity in the developing brain and MMP-knockout studies reporting CNS defects, suggest that MMPs play a crucial role in neural development (Mendez-Otero et al., 2005). Most recently, MMPs have been suggested as physiological regulators of synaptic activity in hippocampus, learning and memory, control of brain function by regulating neurogenesis, cell migration, topographic mapping, axon guidance, myelination and synaptogenesis, as well as are recognized as detrimental proteinases in neurological disorders (Agrawal et al., 2008).

MMPs, initially found in the tadpole tail undergoing morphogenesis (Brinckeroff and Matrisian, 2002; Gross and Lapiere, 1962) have surely run a long distance reaching adult human CNS (Yong et al., 2001), demonstrating to be not only bulldozers which degrade and destroy extracellular matrix components but instead revealing roles as fundamental components of the intricate machinery that rule and govern NSC fate and determination. MMPs display distinct and precise expression patterns in the CNS indicating their importance in the temporal and spatial regulation of CNS microenvironment. Tightly regulated MMP expression may reflect successive stages of brain development suggesting their involvement during many steps of neural differentiation. MMPs are known for the capacity to modify in a finely regulated manner the extracellular matrix, creating even just slight modifications that may however have great importance. In fact, the signals generated from MMPs through the modification/processing of matrix and non-matrix components act in a double manner; MMPs modify the external environment generating extracellular signals (due to the degradation of matrix proteins and release of matricryptic sites or molecules, or to the activation/inhibition of molecules "hidden" and sequestered in the ECM) which in turn have effects on the neighbouring cells, thus creating a cross-talk between the cell and the external matrix, two entities linked together by the action of MMPs. The highly controlled proteolytic activity may generate a niche where NSCs receive the information needed for their differentiation and fate decision. Even though many studies are needed to disclose the complexity underlying 
neurogenesis in the adult CNS, it can be surely stated that MMPS may regulate the process, by being involved in the biological mechanisms that from a multipotent neural stem cell generate highly differentiated and specialized cells, such as neurons, oligodendrocytes and astrocytes. In this respect, a recent evidence highlights the importance of gelatinases within the hypothalamic supraoptic nuclei, demonstrating that noradrenaline may trigger MMP-2 and MMP-9 gelatinolytic activities of neurons and astrocytes, regulating both chemical and structural plasticity (Maolood et al., 2008).

It has been surprising enough to see MMPs involved in the differentiation of mesenchymal stem cells into neural lineage (Mannello, 2006a), but even more surprising would it be to uncover the possible roles of MMPs in the differentiation of NSCs into neurons, astrocytes and oligodendrocytes (Mannello et al., 2006).

\section{Acknowledgements}

We would like to thank Ms. Eleonor Cencherle for the careful assistance in English revision.

\section{References}

ABERG, M.A. (2003) IGF-1 has a direct proliferative effect in adult hippocampal progenitor cells. Mol. Cell Neurosci. 24: 23-40.

AGRAWAL, S.M., LAU, L. and YONG, V.W. (2008) MMPs in the Central Nervous System: where the good guys go bad. Semin. Cell Dev. Biol. 19: 42-51.

ALTMAN J (1962) Are new neurons formed in the brains of adult mammals? Science 135: 1127-1128.

ALTMAN J and DAS GD (1965) Autoradiographic and histological evidence of postnatal hippocampal neurogenesis in rats. J. Comp. Neurol. 124: 319-335.

ALVARES-BUYLLA, A., GARCIA-VERDUGO, J.M. and TRAMONTIN, A.D. (2001) A unified hypothesis on the lineage of neural stem cells. Nat. Rev. 2: 287-292.

AMOUREUX, M.C., CUNNINGHAM, B.A., EDELMAN, G.M. and CROSSIN, K.L. (2000) N-CAM binding inhibits the proliferation of hippocampal progenitor cells and promotes their differentiation to a neural phenotype. J. Neurosci. 20: 36313640.

ANELLI, T., MANNELLO, F., SALANI, M., TONTI, G.A., POIANA, G. and BIAGIONI, S. (2007) Acetylcholine induces neurite outgrowth and modulates matrix metalloproteinases 2 and 9. Biochem.Biophys. Res. Commun. 362: 269-274.

ARVIDSSON, A.,COLLIN, T., KIRIK, D., KOKAIA, Z. and LINDVALL., O. (2002) Neuronal replacement from endogenous precursors in the adult brain after stroke. Nat. Med. 8: 963-970.

AYOUB, A.E., CAI, T.Q., KAPLAN, R.A. and LUO, J. (2005) Developmental expression of matrix metalloproteinases 2 and 9 and their potential role in the histogenesis of the cerebellar cortex. J. Comp. Neurol. 481: 403-415.

AZKLARCZYK, A., LAPINSKA, J., RYLSKI, M., MCKAY, R.D.G. and KACZMAREK, L. (2002) Matrix metalloproteinase-9 undergoes expression and activation during dendritic remodelling in adult hippocampus. J. Neurosci. 22: 920-930.

BAIN G, KITCHENS D, YAO M, HUETTNER JE and GOTTLIEB DI (1995) Embryonic stem cells express neuronal properties in vitro. Dev Bio/168: 342357.

BATTISTA, D., FERRARI, C.C., GAGE, F.H. and PITOSSI, F.J. (2006) Neurogenic niche modulation by activated microglia: transforming growth factor beta increases neurogenesis in the adult dentate gyrus. Eur. J. Neurosci. 23: 83-93.

BEGGS, H.E., SORIANO, P. and MANESS, P.F. (1994) NCAM-dependent neurite outgrowth is inhibited in neurons from Fyn-minus mice. J. Cel/ Biol. 127: 825833.

BELACHEW S, CHITTAJALLU R, AGUIRRE AA, YUAN X, KIRBY M, ANDERSON $S$ and GALLO V (2003) Postnatal NG2 proteoglycan-expressing progenitor cells are intrinsically multipotent and generate functional neurons. J. Cell. Biol. 161: 169-186.

BELLUZZI O, BENEDUSI M, ACKMAN J and LOTURCO JJ (2003) Electrophysi- ological differentiation of new neurons in the olfactory bulb. J. Neurosci. 23: 10411-10418.

BELVINDRAH, R., ROUGON, G. and CHAZAL, G. (2002) Increased neurogenesis in adult mCD24-deficient mice. J. Neurosci. 22: 3594-3607.

BENGZON, J., KOKAIA, Z., ELMER, E., NANOBASHVILI, A., KOKAIA, M. and LINDVALL, O. (1997) Apoptosis and proliferation of dentate gyrus neurons after single and intermittent limbic seizures. Proc. Natl. Acad. Sci. USA 94: 1043210437.

BEN-HUR, T., BEN-YOSEF, Y., MIZRACHI-KOL, R., BEN-MENACHEM, O. and MILLER, A. (2006) Cytokine-mediated modulation of MMPs and TIMPs in multipotential neural precursor cells. J. Neuroimmunol. 175: 12-18.

BIBEL, M., RICHTER, J., SCHRENK, K., TUCKER, K.L., STAIGER, V., KORTE, M., GOETZ, M. and BARDE, Y.A. (2004). Differentiation of mouse embryonic stem cells into a defined neuronal lineage. Nat. Neurosci. 7: 1003-1009.

BIGG, H.F., MORRISON, C.J., BUTLER, G.S., BOGOYEVITCH, M.A., WANG, Z.P and SOLOAY, P.D. (2001) Tissue inhibitor of metalloproteinases-4 inhibits but does not support the activation of gelatinase $A$ via efficient inhibition of membrane type 1-matrix metalloproteinases. Cancer Res. 61: 3610-3618.

BIGG, H.F, SHI., Y.E., LIU, Y.E., STEFFENSEN, B. and OVERALL, C.M. (1997) Specific, high affinity binding of tissue inhibitors of metalloproteinases-4 (TIMP4) to the $\mathrm{COOH}$-terminal hemopexin-like domain of human gelatinase A. TIMP4 binds progelatinase $\mathrm{A}$ and the $\mathrm{COOH}$-terminal domain in a similar manner to TIMP-2. J. Biol. Chem. 272: 15496-15500.

BODE, W., GOMIS-RÜTH, F.Z. and STÖCKLER, W. (1993) Astacins, serralysins, snake venom and matrix metalloproteinases exhibit identical zinc-binding environments (HEXXHXXGXXH and Met-turn) and topologies and should be grouped into a common family, the "metzincins". FEBS Lett. 331: 134-140.

BOURGUIGNON, L.Y., GUNJA-SMITH, Z., IIDA, N., ZHU, H.B., and YOUNG, L.J. (1998) CD44v(3,8-10) is involved in cytoskeleton-mediated tumor cell migration and matrix metalloproteinase (MMP-9) association in metastatic breast cancer cells. J. Cell. Physio. 176: 206-215.

BOVETti, S., BOVOliN, P., PERROTEAU, I. and PUCHE, A.C. (2007) Subventricular zone-derived neuroblast migration to the olfactory bulb is modulated by matrix remodelling. Eur. J. Neurosci. 25: 2021-2033.

BRAUN, H., SCHAFER, K. and HOLLT, V. (2002) Betalll tubulin-expressing neurons reveal enhanced neurogenesis in hippocampal and cortical structures after a contusion trauma in rats. J. Neurotrauma 19: 975-983.

BRINCKERHOFF, C.E. and MATRISIAN, L.M. (2002) Matrix metalloproteinases: a tail of a frog that became a prince. Nature 3: 207-214.

BROOKS, P.C., STROMBLAD, S., SANDERS, L.C., VON SCHALSCHA, T.L., and AIMES, R.T. (1996) localization of matrix metalloproteinase MMP-2 to the surface of invasive cells by interaction with integrin $\alpha v \beta 3$. Cel/85: 683-693.

BRUSTLE O, JONES KN, LEARISH RD, KARRAM K, CHOUDHARY K, WIESTLER OD, DUNCAN ID and MCKAY RD (1999) Embryonic stem cell-derived glial precursors: a source of myelinating transplants. Science 285: 754-756.

BUFFO A, RITE I, TRIPATHI P, LEPIER A, COLAK D, HORN AP, MORI T and GOTZ M (2008) Origin and progeny of reactive gliosis: A source of multipotent cells in the injured brain. Proc. Natl. Acad. Sci. USA 105: 3581-3586.

BURRAGE, P.S., MIX, K.S. and BRINCKERHOFF, C.E. (2006) Matrix metalloproteinases: role in arthritis. Front. Biosci. 11: 529-543.

BUTLER, G.S., APTE, S.S., WILLENBROCK, F. and MURPHY, G. (1999) Human tissue inhibitor of metalloproteinase 3 interacts with both the $\mathrm{N}$ - and C-terminal domains of gelatinase A and B, regulation by polyanions. J. Biol. Chem. 274: 10846-10851.

BUTOVSKY, O., ZIV, Y., SCHWARTZ, A., LANDA, G., TALPALAR, AE., PLUCHINO, S., MARTINO, G. and SCHWARTZ, M. (2006) Microglia activated by IL-4 or IFNgamma differentially induce neurogenesis and oligodendrogenesis from adult stem/progenitor cells. Mol. Cell Neurosci. 31: 149-160.

CACCI, E, AJMONE-CAT, M.A., ANELLI, T., BIAGIONI, S. and MINGHETTI, L. (2008) In vitroneuronal and glial differentiation from embryonic or adult neural precursor cells are differently affected by chronic or acute activation of microglia. Glia 56: 412-425.

CACCI, E., VILLA, A., PARMAR, M., CAVALLARO, M., MANDAHL, N., LINDVALL, O., MARTINEZ-SERRANO, A. and KOKAIA, Z. (2007) Generation of human cortical neurons from a new immortal foetal neural stem cell line. Exp.Cell Res. 313: $588-601$. 
CAJAL, S. (1913) Estudios sobre la degeneracion y regeneracion del sistema nervioso. Tomo I, Degeneracion y regeneracion de los nervios. Madrid: Imprenta de Hijos de Nicolas Moya.

CAMERON, H.A. and GOULD, E. (1994) Adult neurogenesis is regulated by adrenal steroids in the DG. Neurosci. 61: 203-209.

CAMERON HA and MCKAY RD (2001) Adult neurogenesis produces a large pool of new granule cells in the dentate gyrus. J. Comp. Neurol. 435: 406-417.

CAMERON HA, WOOLLEY CS, MCEWEN BS and GOULD E (1993) Differentiation of newly born neurons and glia in the dentate gyrus of the adult rat. Neuroscience 56 : $337-344$.

CAO, L. (2004) VEGF links hippocampal activity with neurogenesis, learning and memory. Nat. Genet. 36: 827-835.

CARPENTER, M.K., CUI, X, HU, Z.Y., JACKSON, J., SHERMAN, S., SEIGER, A. and WAHLBERG, L.U. (1999) In vitro expansion of a multipotent population of human neural progenitor cells. Exp. Neurol. 158: 265-278.

CAUWE, B., VAN DEN STEEN, P.E. and OPEDENAKKER, G. (2007) The biochemical, biological, and pathological kaleidoscope of cell surface substrates processed by matrix metalloproteinases. Crit. Rev. Biochem. Mol. Biol. 42: 113185.

CHAMBAUT-GUERÌN, A.M., HENGAULT, S., ROUET-BENZINEB, P., ROUCHER, C. and LAFUMA, C. (2000) Induction of matrix metalloproteinase MMP-9 (92$\mathrm{kDa}$ gelatinase) by retinoic acid in human neuroblastoma SKNBE cells: relevance to neuronal differentiation. J. Neurochem. 74:506-517.

CHAMBAUT-GUERIN, A.M., ROUCHER, C. and GAUTHEREAU, X. (1995) Tumor necrosis factor receptor in neuroblastoma SKNBE cells and their regulation by retinoic acid. J. Neurochem. 65:537-544.

CHIASSON, B.J., TROPEPE, V., MORSHEAD, C.M. and VAN DER KOOY, D. (1999) Adult mammalian forebrain ependymal and subependymal cells demonstrate proliferative potential, but only subependymal cells have neural stem cell characteristics. J..Neurosci. 19:4462-4471.

CHRISTOPHERSON, K.S., ULLIAN, E.M., STOKES, C.C., MULLOWNEY, C.E., HELL, J.W., AGAH, A., LAWLER, J., MOSHER, D.F., BORNSTEIN, P. and BARRES, B.A. (2005) Thrombospondins are astrocyte-secreted proteins that promote CNS synaptogenesis. Cel/120: 421-433.

CIANI, L. and SALINAS, P.C. (2005) WNTs in the vertebrate nervous system: from patterning to neuronal connectivity. Nat. Rev. Neurosci. 6: 351-362.

CLARK, I.M., SWINGLER, T.E., SAMPIERI, C.L. and EDWARDS, D.R. (2008) the regulation of matrix metalloproteinases and their inhibitors. Int. J. Biochem. Cell Biol, DOI: 10.1016/j.biocel.2007.12.006.

CONTI, L., POLLARD, S.M., GORBA, T., REITANO, E., TOSELLI, M., BIELLA, G., SUN, Y., SANZONE, S., YING, Q.L., CATTANEO, E. and SMITH, A. (2005) Niche-independent symmetrical self-renewal of a mammalian tissue stem cell. PLOS. Biol. 3: e283.

CORBITT, C.A., LIN, J. and LINDSEY, M.L. (2007) Mechanisms to inhibit matrix metalloproteinase activity: where are we in the development of clinically relevant inhibitors? Recent Patents Anti-Cancer Drug Discov. 2: 135-142.

COSKUN, V., WU, H., BLANCHI, B., TSAO, S., KIM, K., ZHAO, J., BIANCOTTI, J.C., HUTNICK, L., KRUEGER, R.C., Jr., FAN, G.G., de VELLIS, J. and SUN, Y.E. (2008). CD133+ neural stem cells in the ependyma of mammalian postnatal forebrain. Proc. Natl. Acad. Sci. USA 105: 1026-1031.

CRAIG, C.G. (1996) In vivogrowth factor expansion of endogenous subependymal neural precursor cell populations in the adult mouse brain. J. Neurosci. 16: 2649-2658.

CRAIG, C.G., D'SA, R., ROACH, A. and VAN DER KOOY, D. (1999) Migrational analysis of the constitutively proliferating subependyma population in adult mouse forebrain. Neurosci. 93: 1197-1206.

DASH, P.K., MACH, S.A. and MOORE, A.N. (2001) Enhanced neurogenesis in the rodent hippocampus following traumatic brain injury. J. Neurosci. Res. 63: 313319.

DAVIS, A.A., TEMPLE, S. (1994) A self-renewing multipotential stem cell in embryonic rat cerebral cortex. Nature 372: 263-266.

DOETSCH, F., CAILLE, I., LIM, D.A., GARCIA-VERDUGO, J.M. and ALVARESBUYLLA, A. (1999) Subventricular zone astrocytes are neural stem cells in the adult mammalian brain. Ce//97: 703-716.

DOETSCH F, GARCIA-VERDUGO JM and ALVAREZ-BUYLLA A (1997) Cellular composition and three-dimensional organization of the subventricular germinal zone in the adult mammalian brain. J. Neurosci. 17: 5046-5061.

DOETSCH, F. and HEN, R. (2005) Young and excitable: the function of new neurons in the adult mammalian brain. Curr. Opin. Neurobiol. 15: 121-128.

DUCHOSSOY, Y., HORVAT, J.C. and STETTLER, O. (2001) MMP-related gelatinase activity is strongly induced in scar tissue of injured adult spinal cord and forms pathways for ingrowing neuritis. Mod. Cell Neurosci. 17: 945-956.

DZWONEK, J., MARCIN, R. and KACZMAREK, L. (2004) Matrix metalloproteinases and their endogenous inhibitors in neuronal physiology of the adult brain. FEBS Letter 567: 129-135.

EGEBLAND, M. and WERB, Z. (2002) New functions for the matrix metalloproteinases in cancer progression. Nature Rev. Cancer2: 161-174.

EKDAHL, C.T., CLAASEN, J.H., BONDE, S., KOKAIA, Z. and LINDVALL, O. (2003) Inflammation is detrimental for neurogenesis in adult brain. Proc. Natl. Acad. Sci. USA 100: 13632-13637.

EMSLEY, J.G. and HAGG, T. (2003) Endogenous and exogenous ciliary neurotrophic factor enhances forebrain neurogenesis in adult mice. Exp. Neurol. 183: 298-310.

ERIKSSON PS, PERFILIEVA E, BJORK-ERIKSSON T, ALBORN AM, NORDBORG C, PETERSON DA and GAGE FH (1998) Neurogenesis in the adult human hippocampus. Nat. Med. 4:.1313-1317.

ETHELL, I.M. and ETHELL, D.W. (2007) Matrix metalloproteinases in brain development and remodelling, synaptic functions and targets. J. Neurosci. Res. 85: 2813-2823.

FAN, X.T., XU, H.W., CAI, W.Q., YANG, H. and LIU, S. (2004) Antisense Noggin oligodoxynucleotide administration decreases cell proliferation in the DG of adult rats. Neurosci. Lett 366: 107-111.

FLAX, J.D., AURORA, S., YANG, C., SIMONIN, C., WILLS, A.M., BILLINGHURST, L.L., JENDOUBI, M., SIDMAN, R.L., WOLFE, J.H., KIM, S.U. and SNYDER, E.Y. (1998) Engraftable human neural stem cells respond to developmental cues, replace neurons, and express foreign genes. Nat. Biotechnol. 16: 10331039.

FRISCH, S.M. and RUOSLAHTI, E. (1997) Integrins and anoikis. Curr. Opin. Cell Biol. 9: 7017-06.

FROLICHSTHAL-SCHOELLER, P., VESCOVI, P., ANGELO, A., KREKOSKI, C.A., MURPHY, G. and EDWARDS, D.R. (1999) Expression and modulation of matrix metalloproteinase-2 and tissue inhibitor of matrix metalloproteinase in human embryonic CNS stem cells. Neurorep. 10: 354-351.

GAGE, F.H. (2000) Mammalian neural stem cells. Science 287: 1433-1438.

GALKO, M.J. and TESSIER-LAVIGNO, M. (2000) Function of an axonal chemoattractant modulated by metalloprotease activity. Science 289: 13651367.

GALLI, R., GRITTI, A., BONFANTI, L. and VESCOVI, A.L. (2003) Neural stem cells: an overview. Circ. Res. 92: 598-608.

GARCIA, A.D., DOAN, N.B., IMURA, T., BUSH, T.G. and SOFRONIEW, M.V. (2004) GFAP-expressing progenitors are the principal source of constitutive neurogenesis in adult mouse forebrain. Nat. Neurosci. 7: 1233-1241.

GARNEAU, N.L., WILUSZ, J., and WILUSZ, C.J. (2007) the highways and byways of mRNA decay. Nat. Rev. Mol, Cell. Biol. 8: 113-126.

GOTTSCHALL, P.E. and DEB, S. (1996) Regulation of matrix metalloproteinase expression in astrocytes, microglia and neurons. Neuroimmunomodulation 3 : 69-75.

GOTZ M and BARDE YA (2005) Radial glial cells defined and major intermediates between embryonic stem cells and CNS neurons. Neuron 46: 369-372.

GOULD, E., REEVES, A.J., FALLAH, M., TANAPAT, P., GROSS, C.G., FUCHS, E. (1999) Hippocampal neurogenesis in adult Old World primates. Proc. Nat/. Acad. Sci. USA 96: 5263-5267.

GRITTI A, PARATI EA, COVA L, FROLICHSTHAL P, GALLI R, WANKE E, FARAVELLI L, MORASSUTTI DJ, ROISEN F, NICKEL DD and VESCOVI AL (1996) Multipotential stem cells from the adult mouse brain proliferate and selfrenew in response to basic fibroblast growth factor. J. Neurosci. 16: 1091-1100.

GRITTI, A., VESCOVI, A.L. and GALLI, R. (2002) Adult neural stem cells: plasticity and developmental potential. J. Physiol. Paris 96: 81-90.

GROSS, J. and LAPIERE, C.M. (1962) Collagenolytic activity in amphibian tissues: a tissue culture assay. Proc. Natl. Acad. Sci. USA 48: 1014-1022. 
HALL, P.E., LATHIA, J.D., MILLER, N.G.A., CALDWELL, M.A. and FRENCHCONSTANT, C. (2006) Integrins are markers of human neural stem cells. Stem Cel/s 24: 2078-2084.

HAMANO, Y., ZEISBERG, M., SUGIMOTO, H., LIVELY, J.C., MAESHIMA, Y., YANG, C., HYNES, R.O., WERB, Z., SUDHAKAR, A. and KALLURI, R. (2003) Physiological levels of tumstatin, a fragment of collagen IV $\alpha 3$ chain, are generated by MMP-9 proteolysis and suppress angiogenesis via $\alpha \mathrm{V} \beta 3$ integrin. Cancer Cel/3: 589-601.

HASTY, K.A., POURMOTABBED, T.F., GOLDBERG, G.I., THOMPSON, J.P., and SPINELLA, D.G. (1990) Human neutrophil collagenase. A distinct gene product with homology to other matrix metalloproteinases. J. Biol. Chem. 265: 1142111424.

HATTORI, M., OSTERFIELD, M. and FLANAGAN, J.G. (2000) Regulated cleavage of a contact-mediated axon repellent. Science 289: 1360-1365.

HEINS N, MALATESTA P, CECCONI F, NAKAFUKU M, TUCKER KL, HACK MA CHAPOUTON P, BARDE YA and GOTZ M (2002) Glial cells generate neurons: the role of the transcription factor Pax6. Nat. Neurosci. 5: 308-315.

HOWARD, E.W. and BANDA, M.J. (1991) Binding of tissue inhibitor of metalloproteinase 2 to two distinct sites on human 72-kDa gelatinase. Identification of a stabilization site. J. Biol. Chem. 266: 17972-17977.

ITOH, Y. and SEIKI, M. (2006) MT1-MMP: a potent modifier of pericellular microenvironment. J. Cell Physiol. 206: 1-8.

JAWORSKI, D.M. and PEREZ-MARTINEZ, L. (2006) Tissue inhibitor of metalloproteinase-2 (TIMP-2) expression is regulated by multiple neural differentiation signals. J. Neurochem. 98: 234-247.

JIN, K. (2002) Vascular endothelial growth factor (VEGF) stimulate neurogenesis in vitro and in vivo. Proc. Natl. Acad. Sci. USA, 99: 11946-11950.

JIN, K. (2003) Cerebral neurogenesis is induced by intranasal administration of growth factors. Ann. Neurol. 53: 405-409.

JIN, K. (2003) Neurogenesis and aging: FGF-2 and HB-EGF restore neurogenesis in hippocampus and subventricular zone of aged mice. Aging Ce//2: 175-183.

JOHANSSON, C.B., MOMMA, S. and CLARKE, D.L. (1999) Identification of a neural stem cell in the adult mammalian Central Nervous System. Cel/96: 2534.

KACZMAREK, L., LAPINSKA-DZWONEK, J. and SZYMCZAK, S. (2002) Matrix metalloproteinase in the adult brain physiology: a link between c-Fos, AP-1 and remodelling of neuronal connections? EMBO J. 21: 6643-6648.

KALLUR, T., DARSALIA, V., LINDVALL, O. and KOKAIA, Z. (2006) Human fetal cortical and striatal neural stem cells generate region-specific neurons in vitro and differentiate extensively to neurons after intrastriatal transplantation in neonatal rats. J. Neurosci. Res. 84: 1630-1644.

KAPLAN MS and HINDS JW (1977) Neurogenesis in the adult rat: electron microscopic analysis of light radioautographs. Science 197: 1092-1094.

KATOH-SEMBA, R. (2002) Riluzole enhances expression of brain-derived neurotrophic factor with consequent proliferation of granule precursor cells in the rat hippocampus. FASEB J. 16: 1328-1330.

KEMPERMANN, G., WISKOTT, L. and GAGE, F.H. (2004) Functional significance of adult neurogenesis. Curr. Opin. Neurobiol. 14: 186-191.

KJELDSEN, L., JOHNSEN, A.H., SENGELOV, H. and BORREGAARD, N. (1993) Isolation and primary structure of NGAL, a novel protein associated with human neutrophil gelatinase. J. Biol. Chem. 268: 10425-10432.

KOKAIA, Z., THORED, P., ARVIDSSON, A. and LINDVALL, O. (2006) Regulation of stroke-induced neurogenesis in adult brain: recent scientific progress. Cereb. Cortex 16 (Suppl 1): i162-167.

KOMURO, H. and RAKIC, P. (1998) Distinct modes of neuronal migration in different domains of developing cerebellar cortex. J. Neurosci. 18: 1478-1490.

KUHN, H.G., DICKINSON-ANSON, H. and GAGE, F.H. (1996) Neurogenesis in the dentate gyrus of the adult rat: age-related decrease of neuronal progenitor proliferation. J. Neurosci. 16: 2027-2033

LARSEN, PH., DASILVA, A.G., CONANT, K. and YONG, V.W. (2006) Myelin formation during development of the CNS is delayed in matrix metalloproteinase9 and -12 null mice. J. Neurosci. 26: 2207-2214.

LEE, S.R., KIM. H.Y., ROGOWSKA, J., ZHAO, B.Q., BHIDE, P. and PARENT, J.M. (2006) Involvement of matrix metalloproteinase in neuroblast cell migration from the subventricular zone after stroke. J. Neurosci. 26: 3491-3495.
LEMKINE, G.F. (2005) Adult neural stem cell cycling in vivo requires thyroid hormone and its $\alpha$ receptor. FASEB J. 19: 863-865.

LEONTOVICH, A.A., ZHANG, J., SHIMOKAWA, K., NAGASE, H. and SARRAS, MP. JR. (2000) A novel hydra matrix metalloproteinases (HMMP) functions in extracellular matrix degradation, morphogenesis and the maintenance of differentiated cells in the foot process. Development 127: 907-920.

LEPAGE, T. and GACHE, C. (1990) Early expression of a collage-like hatching enzyme gene in the sea urchin embryo. EMBO J. 9: 3003-3012.

LIE, D.C., COLAMARINO, S.A., SONG, H.J., DESIRE, L., MIRA, H., CONSIGLIO, A., LEIN, E.S., JESSBERGER, S., LANSFORD, H., DEARIE, A.R. and GAGE, F.H. (2005) Wnt signalling regulates adult hippocampal neurogenesis. Nature 437: $1370-1375$

LIE, D.C., SONG, H., COLAMARINO, S.A., MING, G.L. and GAGE, F.H. (2004) Neurogenesis in the adult brain: new strategies for Central Nervous System diseases. Annu. Rev. Pharmacol. Toxicol. 44: 399-421.

LIM, D.A. (2000) Noggin antagonizes BMP signalling to create a niche for adult neurogenesis. Neuron, 28: 713-726.

LINDVALL, O. and KOKAIA, Z. (2005) Stem cell therapy for human brain disorders Kidney Int. 68: 1937-1939.

LIU J, SOLWAY K, MESSING RO and SHARP FR (1998) Increased neurogenesis in the dentate gyrus after transient global ischemia in gerbils. J. Neurosci. 18: 7768-7778.

LLANO, E., PENDAS, A.M., AZA-BLANC, P., KORNBERG, TB. and LOPEZ-OTIN, C. (2000) Dm1-MMP, a matrix metalloproteinase from Drosophila with a potential role in extracellular matrix remodelling during neural development. $J$. Biol. Chem. 275: 35978-35985.

LLEDO, P.M., ALONSO, M. and GRUBB, MS. (2006) Adult neurogenesis and functional plasticity in neuronal circuits. Nat. Rev. Neurosci. 7: 179-193.

LOHI, J., LEHTI, K., VALTANEN, H., PARKS, W.C., and KESKI-OJA, J. (2000) Structural analysis and promoter characterization of the human membrane-type matrix metalloproteinase-1 (MT1-MMp) gene. Gene 242: 75-86.

LOIA, C., GARCIA-VERDUGO, J. and ALVAREZ-BUYLLA, A. (1996) Chain migration of neuronal precursors. Science 271: 978-981.

LOIS C and ALVAREZ-BUYLLA A (1993) Proliferating subventricular zone cells in the adult mammalian forebrain can differentiate into neurons and glia. Proc. Natl. Acad. Sci. USA 90: 2074-2077.

LOIS, C. and ALVAREZ-BUYLLA, A. (1994) Long-distance neuronal migration in the adult mammalian brain. Science 264: 1145-1148.

LUO, J. (2005) The role of matrix metalloproteinases in the morphogenesis of the cerebellar cortex. Cerebellum 4: 239-245.

LUSKIN, M.B. (1993) Restricted proliferation and migration of postnatally generated neurons derived from the forebrain subventricular zone. Neuron 11: 173189.

MA, DK., MING, G. and SONG, H. (2005) Glial influences on neural stem cell development: cellular niches for adult neurogenesis. Curr. Opin. Neurobiol. 15: 514-520.

MADANI, R., HULO, S., TONI, H., STEIMER, T., MULLER, D. and VASSALLI, J.D. (1999) Enhanced hippocampal long-term potentiation and learning by increased neuronal expression of tissue-type plasminogen activator in transgenic mice. EMBO J. 18: 3007-3012.

MALATESTA P, HARTFUSS E and GOTZ M (2000) Isolation of radial glial cells by fluorescent-activated cell sorting reveals a neuronal lineage. Development 127: 5253-5263.

MANCINI. A. and DI BATTISTA, J.A. (2006) Transcriptional regulation of matrix metalloproteinase gene expression in health and diseases. Front. Biosci. 11: 423-446.

MANNELLO, F. and GAZZANELLI, G. (2001) Tissue inhibitors of metalloproteinases and programmed cell death: conundrums, controversies and potential implications. Apoptosis 6: 479-482.

MANNELLO, F., LUCHETTI, F., FALCIERI, E. and PAPA, S. (2005a) Multiple roles of matrix metalloproteinases during apoptosis. Apoptosis 10: 19-24.

MANNELLO, F., TONTI, G., BAGNARA, G.P. and PAPA, S. (2006) Role and function of matrix metalloproteinases in the differentiation and biological characterization of mesenchymal stem cell. Stem Cells 24: 475-481.

MANNELLO, F., TONTI, G. and PAPA, S. (2005b) Are matrix metalloproteinases 
the missing link? Invert. Surv. J. 2: 69-74.

MANNELLO, F., TONTI, G. and PAPA, S. (2005c) Matrix metalloproteinase inhibitor as anticancer therapeutics. Curr. Cancer Drug Targets. 5: 285-298.

MANNELLO, F. (2006a) Multipotent mesenchymal stromal cell recruitment, migration, and differentiation: what have matrix metalloproteinases got to do with it? Stem Cells 24: 1904-1907.

MANNELLO, F. (2006b) Natural bio-drugs as matrix metalloproteinase inhibitors: new perspectives on the horizon? Recent Patents Anticancer Drug Discov. 1: 91-103.

MAOLOOD, N., HARDIN-POUZET, H. and GRANGE-MESSENT, V. (2008) Matrix metalloproteinases MMP2 and MMP9 are upregulated by noradrenaline in the mouse neuroendocrine hypothalamus. Eur. J. Neurosci. 27: 1143-1152.

MARKAKIS, E.A. and GAGE, F.H. (1999) Adult-generated neurons in the DG send axonal projections to field CA3 and are surrounded by synaptic vesicles. J. Comp. Neurol. 406: 449-460.

MARTINI, R. (1994) Expression and functional roles of neural cell surface molecules and extracellular matrix components during development and regeneration of peripheral nerve. J. Neurocytol. 23: 1-28.

MASSOVA, I., KOTRA, L.P., FRIDMAN, R. and MOBASHERY, S. (1998) Matrix metalloproteinases: structure, evolution, and diversification. FASEBJ12: 10751095.

MCCAWLEY, L.J. and MATRISIAN, M.N. (2001) Matrix metalloproteinases: they're re not just for matrix anymore! Curr. Opin. Cell Biol. 13: 534-540.

MCQUIBBAN, G.A., GONG, J.H., TAM, E.M., MCCULLOCH, C.A., CLARK-LEWIS, I. and OVERALL, C.M. (2000) Inflammation dampened by gelatinase A cleavage of monocyte chemoattractant protein-3. Science 289: 1202-1206.

MENDEZ-OTERO, R., ZAVERUCHA-DO-VALLE, C., GUBERT, F., DE FREITAS, G.R. and SANTIAGO, M.F. (2005) Regulation and function of neurogenesis in the adult vertebrate brain. Braz. J. Med. Biol. Res. 38: 1553-1559.

MERKLE, F.T., MIRZADEH, Z. and ALVAREZ-BUYLLA, A. (2007) Mosaic organization of neural stem cells in the adult brain. Science 317: 381-384.

MERKLE, F.T. and ALVAREZ-BUYLLA, A. (2006) Neural stem cells in mammalian development. Curr. Opin. Cell Biol. 18: 704-709.

MILWARD, E.A., FITZSIMMONS, C., SZKLARCZYK, A. and CONANT, K. (2007) The matrix metalloproteinases and CNS plasticity: an overview. J. Neuroimmunol. 187: 9-19.

MIZUGUCHI, R., SUGIMORI, M., TAKEBAYASHI, H., KOSAKO, H., NAGAO, M., YOSHIDA, S., NABESHIMA, Y., SHIMAMURA, K. and NAKAFUKU, M. (2001) Combinatorial roles of oligo2 and neurogenin2 in the coordinated induction of pan-neuronal and subtype-specific properties of motoneurons. Neuron 31: 757771.

MONJE, M.L., TODA, H. and PALMER, T.D. (2003) Inflammatory blockade restores adult hippocampal neurogenesis. Science 302: 1760-1765.

MOREST, D.K. and SILVER, J. (2003) Precursors of neurons, neuroglia, and ependymal cells in the CNS: what are they? Where are they from? How do they get where they are going? Glia 43: 6-18.

MORGUNOVA, E., TUUTTILA, A., BERGMANN, U., ISUPOV, M., LINDQVIST, Y. SCHNEIDER, G. and TRYGGVASON, K. (1999) Structure of human pro-matrix metalloproteinase-2: activation mechanism revised. Science 284: 1667-1670.

MORGUNOVA, E., TUUTTILA, A., BERGMANN, U. and TRYGGVASON, K. (2002) Structural insight into the complex formation of latent matrix metalloproteinase 2 with tissue inhibitor of metalloproteinase 2. Proc. Natl. Acad. Sci. USA 99: 7414-7419.

MORSHEAD, C.M., CRAIG, C.G. and VAN DER KOOY, D. (1998) In vivo clonal analyses reveal the properties of endogenous neural stem cell proliferation in the adult mammalian forebrain. Development 125: 2251-2261.

MORSHEAD, C.M., REYNOLDS, B.A., CRAIG, C.G., MCBURNEY, M.W., STAINES, W.A., MORASSUTTI, D., WEISS, S. and VAN DER KOOY, D. (1994) Neural stem cells in the adult mammalian forebrain: a relatively quiescent subpopulation of sub-ependymal cells. Neuron 13: 1071-1082.

MOTT, JD., THOMAS, CL., ROSENBACH, M.T., TAKAHARA, K., GREENSPAN, D.S. and BANDA, M.J. (2000) Post-translational proteolytic processing of procollagen C-terminal proteinase enhancer releases a metalloproteinases inhibitor. J. Biol. Chem. 275: 1384-1390.

MOTT, JD. and WERB, Z. (2004) Regulation of matrix biology by matrix metalloproteinases. Curr. Opin. Cell Biol. 16: 5585-5564.

MURPHY, G., NGUYEN, Q., COCKETT, M.I., ATKINSON, S.J. and ALLA, J.A. (1994) Assessment of the role of the fibronectin-like domain of gelatinase $A$ by analysis of a detection mutant. J. Biol. Chem. 248: 496-510.

MURPHY, G. and WILLENBROCK, F. (1995) Tissue inhibitors of matrix metalloendopeptidases. Methods Enzymol. 248: 496-510.

NAGASE, H. (1997) Activation mechanisms of matrix metalloproteinases. Biol. Chem. 378: 151-160.

NAGASE, H., VISSE, R. and MURPHY, G. (2006) Structure and function of matrix metalloproteinases and TIMPs. Cardiovasc. Res. 69: 562-573.

NAGASE, H. and WOESSNER, J.F. JR. (1999) Matrix metalloproteinases. J. Biol. Chem. 274: 21491-21494.

NAKASHIMA, K., YANAGISAWA, M., ARAKAWA, H., KIMURA, N., HISATSUME, T., KAWABATA, M., MIYAZONO, K. and TAGA, T. (1999) Synergistic signalling in fetal brain by STAT3-Smad1 complex bridge by p300. Science 284: 479-482.

NAKATOMY, H., KURIU, T., OKABE, S., YAMAMOTO, S., HATANO, O., KAWAHARA, N., TAMURA, A., KIRINO, T. and NAKAFUKU, M. (2002) Regeneration of hippocampal pyramidal neurons after ischemic brain injury by recruitment of endogenous neural progenitors. Cel/110: 429-441.

NAVARRO-GALVE, B. and MARTINEZ-SERRANO, A. (2006) «Is there any need to argue..» about the nature and genetic signature of in vitroneural stem cells? Exp. Neurol. 199: 20-25.

NEDERGAARD, M., RANSOM, B. and GOLDMAN, S.A. (2003) New roles for astrocytes: redefining the functional architecture of the brain. Trends Neurosci. 26: 523-530.

NIETO, M., SCHUURMANS, C., BRITZ, O. and GUILLEMOT, F. (2001) Neural bHLH genes control the neuronal versus glial fate decision in cortical progenitors. Neuron 29: 410-413.

NOCTOR SC, FLINT AC, WEISSMAN TA, DAMMERMAN RS and KRIEGSTEIN AR (2001) Neurons derived from radial glial cells establish radial units in neocortex. Nature 409: 714-720.

NUNES MC, ROY NS, KEYOUNG HM, GOODMAN RR, MCKHANN G, 2ND, JIANG L, KANG J, NEDERGAARD M and GOLDMAN SA (2003) Identification and isolation of multipotential neural progenitor cells from the subcortical white matter of the adult human brain. Nat. Med. 9: 439-447

OGIER, C., BERNARD, A., CHOLLET, AM., L.E., DIGUARDHER, T., HANESSIAN, S., CHARTON, G., KHRESTCHATISKY, M. and RIVERA, S. (2006) Matrix metalloproteinase-2 (MMP-2) regulates astrocyte motility in connection with the actin cytoskeleton and integrins. Glia 54:272-284.

OH, L.Y.S., LARSEN, P.H., KREKOSKI, C.A., EDWARDS, D.R., DONOVAN, F and WERB, Z. (1999) Matrix metalloproteinase-9/gelatinase $B$ is required for process outgrowth by oligodendrocytes. J. Neurosci. 19: 8464-8475.

OH, J., TAKAHASHI, R., KONDO, S., MIZOGUCHI, A., ADACHI, E., SASAHARA, RM., NISHIMURA, S., IMAMURA, Y., KITAYAMA, H., ALEXANDER, D.B., IDE, C., HORAN, T.P., ARAKAWA, T., YOSHIDA, H., NISHIKAWA, S., ITOH, Y., SEIKI, M., ITOHARA, S., TAKAHASHI, C. and NODA, M. (2001) The membrane-anchored MMP inhibitor RECK is a key regulator of extracellular matrix integrity and angiogenesis. Ce//107: 789-800.

OKANO, H. (2002) Stem cell biology of the Central Nervous System. J. Neurosci. Res. 69: 698-707.

OSTENFELD, T. and SVENDSEN, CN. (2003) Recent advances in stem cell neurobiology. Adv. Tech. Stand. Neurosurg. 28: 3-89.

OVERALL, C.M. (2002) Molecular determinants of metalloproteinase substrate specificity. Mol. Biotechnol. 22: 51-86.

OVERALL, C.M., WRANA, J.L., and SODEK, J. (1991) transcriptional and posttranscriptional regulation of 72-kDa gelatinase/type IV collagenase by transforming growth factor- $\beta$ in human fibroblasts. Comparison with collagenase and tissue inhibitor of matrix metalloproteinase gene expression. J. Biol. Chem. 266: 14064-14071.

PAGE-MCCAW, A., EWALD, A.Y., and WERB, Z. (2007) Matrix metalloproteinases and the regulation of tissue remodelling. Nature 8: 221-233.

PALMER, T.D., SCHWARTZ, P.H., TAUPIN, P., KASPAR, B., STEIN, S.A. and GAGE, F.H. (2001) Cell culture. Progenitor cells from human brain after death. Nature 411: 42-43.

PALMER, T.D., TAKAHASHI, J. and GAGE, F.H. (1997) The adult rat hippocampus 
contains primordial neural stem cells. Mol. Cell Neurosci. 8: 389-404.

PALMER, T.D. (2002) Adult neurogenesis and the vascular Nietzsche. Neuron34: 856-858.

PALMER, T.D., WILLHOITE, A.R. and GAGE, F.H. (2000) Vascular niche for adult hippocampal neurogenesis. J. Comp. Neurol.-425: 479-494.

PARENT, J.M., VALENTIN, V.V. and LOWENSTEIN, D.H. (2002) Prolonged seizures increase proliferating neuroblasts in the adult rat subventricular zoneolfactory bulb pathway. J. Neurosci. 22: 3174-3188.

PARENT, J.M., YU, T.W., LEIBOWITZ, R.T., GESCHWIND, D.H., SLOVITER, R.S. and LOWENSTEIN, D.H. (1997) Dentate granule cell neurogenesis is increased by seizures and contributes to aberrant network reorganization in the adult rat hippocampus. J. Neurosci. 17: 3727-3738.

PARMAR, M., SKOGH, C., BJORKLUND, A. and CAMPBELL, K. (2002) Regional specification of neurosphere cultures derived from subregions of the embryonic telencephalon. Mol. Cell Neurosci. 21: 645-656.

PATON JA and NOTTEBOHM FN (1984) Neurons generated in the adult brain are recruited into functional circuits. Science 225: 1046-1048.

PEPPER, M.S. (2001) Role of the matrix metalloproteinase and plasminogen activator-plasmin systems in angiogenesis. Arterioscler. Thromb. Vasc. Biol. 21: 1104-1117

POLLARD, S., CONTI, L. and SMITH, A. (2006) Exploitation of adherent neural stem cells in basic and applied neurobiology. Regen. Med. 1: 111-118.

POLLOCK, K., STROEMER, P., PATEL, S., STEVANATO, L., HOPE, A., MILJAN, E., DONG, Z., HODGES, H., PRICE, J. and SINDEN, J.D. (2006) A conditionally immortal clonal stem cell line from human cortical neuroepithelium for the treatment of ischemic stroke. Exp. Neurol. 199: 143-155.

QIAN, X., DAVIS, A.A., GODERIE, S.K. and TEMPLE, S. (1997) FGF2 concentration regulates the generation of neurons and glia from multipotent cortical stem cells. Neuron 18: 81-93.

QIAN, X., SHEN, Q., GODERIE, SK., HE, W., CAPELA, A., DAVIS, A.A. and TEMPLE, S. (2000) Timing of CNS cell generation: a programmed sequence of neuron and glial cell production from isolated murine cortical stem cells. Neuron 28: 69-80.

RA, H.J. and PARKS, W.C. (2007) Control of matrix metalloproteinase catalytic activity. Matrix Biol. 26: 587-596

REYNOLD, BA. and WEISS, S. (1996) Clonal and population analyses demonstrate that an EGF-responsive mammalian embryonic CNS precursor is a stem cell. Dev. Biol. 175: 1-13.

REYNOLDS, B.A. and WEISS, S. (1992) Generation of neurons and astrocytes from isolated cells of the adult mammalian Central Nervous System. Science 255: 1707-1710.

RIDET, J.L., MALHOTRA, S.K., PRIVAT, A. and GAGE, F.H. (1997) Reactive astrocytes: cellular and molecular cues to biological function. Trends Neurosci. 20: 570-577.

ROSENBERG, G.A. (2002) Matrix metalloproteinases in neuroinflammation. Glia 39: 279-291.

SAH, D.W., RAY, J. and GAGE, F.H. (1997) Bipotent progenitor cell lines from the human CNS. Nat. Biotechnol. 15: 574-580.

SEABERG, R.M. and VAN DER KOOY, D. (2002) Adult rodent neurogenic regions: the ventricular subependyma contains neural stem cells, but the dentate gyrus contains restricted progenitors. J. Neurosci. 22: 1784-1793.

SERI, B., GARCIA-VERDUGO, JM., COLLADO-MORENE, L., MCEWEN, BS. and ALVARES-BUYLLA, A. (2004) Cell types, lineages, and architecture of the germinal zone in the adult dentate gyrus. J. Comp. Neurol. 478: 359-378.

SERI, B., GARCIA-VERDUGO, JM. and MCEWEN, BS. (2001) Astrocytes give rise to new neurons in the adult mammalian hippocampus. J. Neurosci. 21: 71537160 .

SHEN, Q. (2004) Endothelial cells stimulate self-renewal and expand neurogenesis neural stem cells. Science 304: 1338-1340.

SHEN, Q., WANG, Y., KOKOVAY, E., LIN, G., CHUANG, S.M., GODERIE, S.K., ROYSAM, B. and TEMPLE, S. (2008). Adult SVZ stem cells lie in a vascular niche: a quantitative analysis of niche cell-cell interactions. Cel/ Stem Cel/ 3: 289-300.

SHIPLEY, JM., DOYLE, GA., FLISAZAR, C.J., YE, Q.Z., JOHNSON, L.L., SHAPIRO, S.D., WELGUS, H.G. and SENIOR, R.M. (1996) The structural basis for the elastolytic activity of the $92-\mathrm{kDa}$ and $72 \mathrm{kDa}$ gelatinases. Role of the fibronectin type II-like repeats. J. Biol. Chem. 271: 4335-4341.

SINGEC, I., KNOTH, R., MEYER, R.P., MACIACZYK, J., VOLK, B., NIKKHAH, G., FROTSCHER, M. and SNYDER, E.Y. (2006) Defining the actual sensitivity and specificity of the neurosphere assay in stem cell biology. Nat. Methods 3: 801806.

SONG, H., STEVENS, CF. and GAGE, F.H. (2002) Astroglia induce neurogenesis from adult neural stem cells. Nature 417: 39-44.

STERNLICHT. M.D. and WERB, Z. (1999) ECM proteinases. In Guidebook to the extracellular matrix, anchor and adhesion proteins, ed. T Kreis, R Valr, pp. 503562. Oxford, UK: Oxford Univ. Press.

STERNLICHT, M.D. and WERB, Z. (2001) How matrix metalloproteinases regulate cell behaviour. Annu. Rev. Cell Dev. Biol. 17: 463-516.

STRONGIN, A.Y., COLLIER, I., BANNIKOV, G., MARMER, B.L., GRANT, G.A. and GOLDBERG, G.I. (1995) Mechanism of cell surface activation of 72-kDa type IV collagenase. Isolation of the activated form of the membrane metalloprotease. J. Biol. Chem. 270: 5331-5338.

STUDER, L. (2001) Stem cells with brainpower. Nat. Biotechno/19: 1117-1118.

SUH, H., CONSIGLIO, A., RAY, J., SAWAI, T., D'AMORE, K.A. and GAGE, F.H. (2007). In vivo fate analysis reveals the multipotent and self-renewal capacities of Sox2+ neural stem cells in the adult hippocampus. Cel/ Stem Cel/1: 515-528.

SUN, Y., POLLARD, S., CONTI, L., TOSELLI, M., BIELLA, G., ARKIN, G., WILLATT, L., FALK, A., CATTANEO, E. and SMITH, A. (2008). Long-term tripotent differentiation capacity of human neural stem (NS) cells in adherent cultures. Mol. Cell Neurosci. 38: 245-258.

SVENDSEN, C.N., BORG, M.G., ARMSTRONG, R.J., ROSSER, A.E., CHANDRAN, S., OSTENFELD, T. and CALDWELL, M.A. (1998) A new method for the rapid and long term growth of human neural precursor cells. J. Neurosci. Methods 85 : 141-152.

TAUPIN, P. and GAGE, G.H. (2002) Adult neurogenesis and neural stem cells of the Central Nervous System in mammals. J. Neurosci. Res 69: 745-749.

TAVAZOJE, M., VAN DER VEKEN, L., SILVA-VARGAS, V., LOUISSANT, M., COLONNA, L., ZAIDI, B., GARCIA-VERDUGO, J.M. and DOETSCH, F. (2008). A specialized vascular niche for adult neural stem cells. Cel/ Stem Cel/3: 279288.

TEMPLE S (1989) Division and differentiation of isolated CNS blast cells in microculture. Nature 340: 471-473.

TEMPLE, S. (2001) The development of neural stem cells. Nature 414: 112-117.

TEMPLE, S. and ALVARES-BUYLLA, A. (1999) Stem cells in the adult mammalian Central Nervous System. Curr. Opin. Neirobiol. 9: 135-141.

THORED, P., ARVIDSSON, A., CACCI, E., AHLENIUS, H., KALLUR, T., DARSALIA, V., EKDAHL, CT., KOKAIA, Z. and LINDVALL, O. (2006) Persistent production of neurons from adult brain stem cells during recovery after stroke. Stem Cells 24: 739-747.

TONI, N., TENG, E.M., BUSHONG, E.A., AIMONE, J.B., ZHAO, C., CONSIGLIO, A., VAN PRAAG, H., MARTONE, M.E., ELLISMAN, M.H. and GAGE FH (2007) Synapse formation on neurons born in the adult hippocampus. Nat. Neurosci. 10: 727-734.

TOTH, M., SADO, Y., NINOMIYA, Y. and FRIDMAN, R. (1999) Biosynthesis of $\alpha 2(\mathrm{IV})$ and $\alpha 1(\mathrm{IV})$ chains of collagen IV and interactions with matrix metalloproteinase-9. J. Cell Physiol. 180: 131-139.

TRAMONTIN, A.D., GARCIA-VERDUGO, J.M., LIM, D.A. and ALVAREZ-BUYLLA, A. (2003) Postnatal development of radial glia and the subventricular zone (VZ): a continuum of the neural stem cell compartment. Cereb. Cortex 13:580-587.

TSUKATANI, T., HELEN, F.L., HAMILTON, H.R., HOLBROOK, E.H. and COSTANZO, R.M. (2003) Matrix metalloproteinase expression in the olfactory epithelium. Neurochem. 14:1135-1140.

UEKI, T. (2003) A novel secretory factor. Neurogenesis-1 provides neurogenic environmental cues for neural stem cells in the adult hippocampus. J. Neurosci. 23: 11732-11740.

UHM, J.H., DOOLEY, N.P., OH, L.Y. and YONG, V.W. (1998) Oligodendrocytes utilize a matrix metalloproteinase, MMP-9, to extend processes along an astrocyte extracellular matrix. Glia 22: 53-63.

ULLIAN, E.M.,,CHRISTOPHERSON, K.S. and BARRES, B.A. (2004) Role for glia in synaptogenesis. Glia 47: 209-216. 
ULRICH, R., GERHAUSER, I., SEELIGER, F., BAUMGARTNER, W. and ALLDINGER, S. (2005) Matrix metalloproteinases and their inhibitors in the developing mouse brain and spinal cord: a reverse transcription quantitative polymerase chain reaction study. Dev. Neurosci27: 408-418.

VAILLANT, C., DIDIER-BAZES, M., HUTTER, A., BELIN, MF. and THOMASSET, N. (1999) Spatiotemporal expression patterns of metalloproteinases and their inhibitors in the postnatal developing rat cerebellum. JNeurosci. 19: 4994-5004.

VAILLANT, C., MEISSIREL, C., MUTIN, M., BELIN, MF., LUND, LR. and THOMASSET, N. (2003) MMP-9 deficiency affects axonal outgrowth, migration, and apoptosis in the developing cerebellum. Mol. Cell Neurosci. 24: 395408.

VAN PRAAG, H., SCHINDER, A.F., CHRISTIE, B.R., TONI, N., PALMER, T.D. and GAGE, F.H. (2002) Functional neurogenesis in the adult hippocampus. Nature 415: 1030-1034.

VAN WART, H.E. and BIRKEDAL-HANSEN, H. (1990) The cysteine switch: a principle of regulation of metalloproteinase activity with potential applicability to the entire matrix metalloproteinase gene family. Proc. Nat/. Acad. Sci. USA, 87: 5578-5582.

VESCOVI, A.L., PARATI, E.A., GRITTI, A., POULIN, P., FERRARIO, M., WANKE, E., FROLICHSTHAL-SCHOELLER, P., COVA, L., ARCELLANA-PANLILIO, M., COLOMBO, A. and GALLI, R. (1999) Isolation and cloning of multipotential stem cells from the embryonic human CNS and establishment of transplantable human neural stem cell lines by epigenetic stimulation. Exp. Neurol. 156: 71-83.

VESCOVI AL, REYNOLDS BA, FRASER DD and WEISS S (1993) bFGF regulates the proliferative fate of unipotent (neuronal) and bipotent (neuronal/astroglial) EGF-generated CNS progenitor cells. Neuron. 11: 951-966.

VILLA, A., SNYDER, E.Y., VESCOVI, A. and MARTINEZ-SERRANO, A. (2000) Establishment and properties of a growth factor-dependent, perpetual neural stem cell line from the human CNS. Exp. Neurol. 161: 67-84.

VILLA, A., RUBIO, F.J., NAVARRO, B., BUENO, C. and MARTANEZ-SERRANO, A. (2001) Human neural stem cells in vitro. A focus on their isolation and perpetuation. Biomed. Pharmacother. 55: 91-95.

VILLA,A., NAVARRO, B. and MARTANEZ-SERRANO, A. (2002) Genetic perpetuation of in vitro expanded human neural stem cells: cellular propensities and therapeutic potential. Brain Res. Bull. 57: 789-794.

VINCENTI, M.P. (2001) The matrix metalloproteinase (MMP) and tissue inhibitor of metalloproteinase (TIMP) genes. In Matrix Metalloproteinase Protocols, ed. IM Clark, pp. 121-148. Totawa, NJ: Humana.

VINCENTI, M.P. and BRINCKERHOFF. C.E. (2007) Signal transduction and celltype specific regulation of matrix metalloproteinase gene expression: can MMPs be good for you? J. Cell Physiol. 213: 355-364.

VISSE, R. and NAGASE, H. (2003) Matrix metalloproteases and tissue inhibitors of metalloproteinases. Circ. Res. 92: 827-839.

VU, T.H., and WERB, Z. (2000) Matrix metalloproteinases: effectors of development and normal physiology. Genes Dev. 17: 2123-2133.

WALTON, N.M., SUTTER, B.M., LAYWELL, E.D., LEVKOFF, L.H., KEARNS, S.M., MARSHALL, G.P. 2ND, SCHEFFLER, B. and STEINDLER, D.A. (2006) Microglia instruct subventricular zone neurogenesis. Glia 54: 815-825.

WANG. L., ZHANG, Z., WANG, Y., ZHANG, R. and CHOPP, M. (2004) Treatment of stroke with erythropoietin enhances neurogenesis and angiogenesis and improves neurological function in rats. Stroke 35: 1732-1737.

WANG, Z., JUTTERMAN, R. and SOLOWAY, P.D. (2000) TIMP-2 is required for efficient activation pf pro-MMP-2 in vivo. J. Biol. Chem. 275: 26411-26415.

WEISS, S., DUNNE, C., HEWSON, J., WOHL, C., WHEATLEY, M., PETERSON, A.C. and REYNOLDS, B.A. (1996) Multipotent CNS stem cells are present in the adult mammalian spinal cord and ventricular neuroaxis. J. Neurosci. 16: 75997609.

WEISS, S. and VAN DER KOOY, D. (1998) CNS stem cells: where's the biology (a.k.a beef)? J. Neurobiol. 36: 307-314.

WILHELM, SM., COLLIER, IE. and MARMER, B.L. (1989) SV40-transformed human lung fibroblasts secrete a 92-kDa type IV collagenase which is identical to that secreted by normal human macrophages. J. Biol. Chem. 263: 1721317221.

YAMAMOTO, N., YAMAMOTO, S., INAGAKI, F., KAWAICHI, M., FUKAMIZU, A., KISHI, N., MATSUNO, K., NAKAMURA, K., WEINMASTER, G., OKANO, H. and NAKAFUKU, M. (2001) Role of Deltex-1 as a transcriptional regulator downstream of the Notch receptor. J.Biol. Chem. 276: 45031-45040.

YAN, C. and BOYD, D.D. (2006) Regulation of matrix metalloproteinase gene expression. J. Cell Physiol. 211: 19-26.

YING QL, STAVRIDIS M, GRIFFITHS D, LI M and SMITH A (2003) Conversion of embryonic stem cells into neuroectodermal precursors in adherent monoculture. Nat. Biotechnol. 21: 183-186.

YONG, V.W., POWER, C., FORSYTH, P. and EDWARDS, D.R. (2001) Metalloproteinases in biology and pathology of the nervous system. Nat. Rev. Neurosci. 2: 502-511.

YOSHIDA, S., SHIOSAKA, S. (1999) Plasticity-related serine proteases in the brain. Int. J. Mol. Med. 3: 405-409.

ZHANG, S., DAILEY, G.M. KWAN, E., GLASHEEN, B.M., SROGA, G.E. and PAGE-MCCAW, A. (2006) An MMP liberates the Ninjurin A ectodomain to signal a loss of cell adhesion. Genes. Dev. 20: 1899-1910.

ZHANG, Y., KLASSEN, H.J., TUCKER, B.A., PEREZ, M.T. and YOUNG, M.J. (2007) CNS progenitor cells promote a permissive environment for neurite outgrowth via a matrix metalloproteinase-2-dependent mechanism. J. Neurosci. 27: 4499-4506.

ZHANG RL, LETOURNEAU Y, GREGG SR, WANG Y, TOHY, ROBIN AM, ZHANG ZG and CHOPP M (2007) Neuroblast division during migration toward the ischemic striatum: a study of dynamic migratory and proliferative characteristics of neuroblasts from the subventricular zone. J. Neurosci. 27: 3157-3162.

ZHAO, B.Q., WANG, S., KIM, H.Y., STORRIE, H., ROSEN, B.R., MOONEY, D.J., WANG, X. and LO, E.H. (2006) Role of matrix metalloproteinases in delayed cortical response after stroke. Nat. Med. 12: 441-445.

ZIV, Y., RON, N., BUTOVSKY, O., LANDA, G., SUDAI, E., GREENBERG, N., COHEN, H., KIPNIS, J. and SCHWARTZ, M. (2006) Immune cells contribute to the maintenance of neurogenesis and spatial learning abilities in adulthood. Nat. Neurosci. 9: 268-275.

ZUO, J., FERGUSON, T.A., HERNANDEZ, Y.J., STETLER-STEVENSON, W.G. and MUIR, D. (1998) Neuronal matrix metalloproteinase-2 degrades and inactivates a neurite-inhibiting chondroitin sulphate proteoglycan. J Neurosci, 18:5203-5211. 


\section{Further Related Reading, published previously in the Int. J. Dev. Biol.}

See our recent Special Issue Fertilization, in honor of David L. Garbers and edited by Paul M. Wassarman and Victor D. Vacquier at: http://www.ijdb.ehu.es/web/contents.php?vol=52\&issue=5-6

See our recent Special Issue Invasion in Cancer \& Embryonic Development, edited by Marc Mareel and Juan Arechaga at: http://www.ijdb.ehu.es/web/contents.php?vol=48\&issue=5-6

From bone marrow to therapeutic applications: different behaviour and genetic/epigenetic stability during mesenchymal stem cell expansion in autologous and foetal bovine sera?

Gaetana A. Tonti and Ferdinando Mannello

Int. J. Dev. Biol. (2008) 52: 1023-1032

A novel, neural potential of non-hematopoietic human umbilical cord blood stem cells

Krystyna Domanska-Janik, Leonora Buzanska and Barbara Lukomska

Int. J. Dev. Biol. (2008) 52: 237-248

Neural differentiation from human embryonic stem cells in a defined adherent culture condition

Hossein Baharvand, Narges-Zare Mehrjardi, Maryam Hatami, Sahar Kiani, Mahendra Rao and Mahdi-Montazer Haghighi

Int. J. Dev. Biol. (2007) 51: 371-378

Matrix metalloproteinases in cancer: from new functions to improved inhibition strategies

Alicia R. Folgueras, Alberto M. Pendás, Luis M. Sánchez and Carlos López-Otín Int. J. Dev. Biol. (2004) 48: 411-424

From hematopoietic stem cells to neural stem cells S Bonilla, P Alarcon, R Villaverde, P Aparicio, A Silva, S Martinez Int. J. Dev. Biol. (2001) 45: S67-S68

An in vitro model to study adult neurogenesis in mammals MP Martin, LM Rodriguez-Perez, J Bermudez-Silva, N Acosta, PF Llebrez-Zayas, M Cifuentes, P Fernandez-Llebrez Int. J. Dev. Biol. (2001) 45: S85-S86

Acetylcholine synthesis and neuron differentiation. S Biagioni, A M Tata, A De Jaco and G Augusti-Tocco Int. J. Dev. Biol. (2000) 44: 689-697

Cell-cell signaling during neurogenesis: some answers and many questions. $\mathrm{K}$ M Bhat Int. J. Dev. Biol. (1998) 42: 127-139

Spinal cord regeneration: a phenomenon unique to urodeles? E A Chernoff Int. J. Dev. Biol. (1996) 40: 823-831

Expression of isoforms of the neural cell adhesion molecule (NCAM) and polysialic acid during the development of the Bufo arenarum olfactory system. D A Paz, D G Alonso, A Pisano, V H Casco, K A Knudsen and A Peralta Soler Int. J. Dev. Biol. (1995) 39: 1005-1013

The avian neural crest as a model system for the study of cell lineages. J Smith

Int. J. Dev. Biol. (1990) 34: 157-162
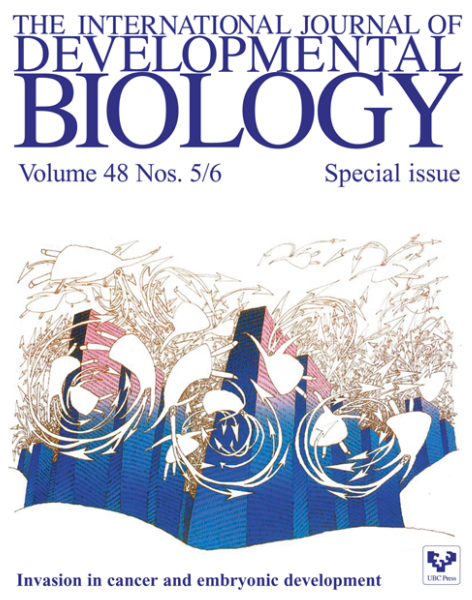

2006 ISI **Impact Factor $=3.577^{* *}$

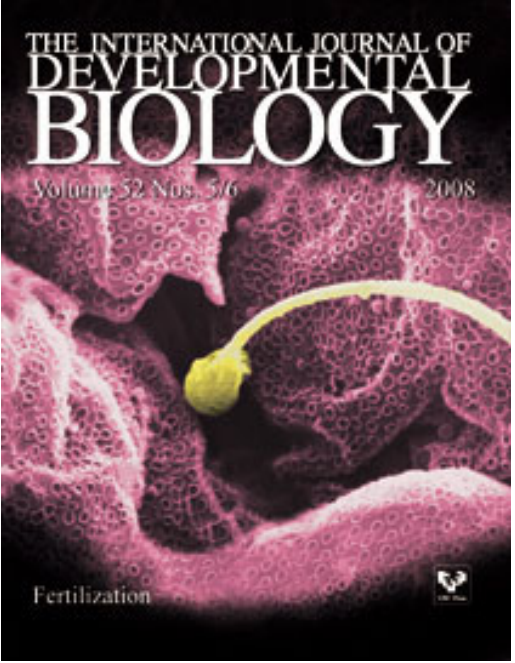

